\title{
Hunting colours: origin and reuse of glass tesserae from the Wierum terp
}

\author{
Rosa Crocco ${ }^{1,2} \cdot$ Hans Huisman ${ }^{1,3}(\mathbb{D}) \cdot$ Yvette Sablerolles $^{4} \cdot$ Julian Henderson $^{4} \cdot$ Bertil van $s^{3} \cdot$ Annet Nieuwhof $^{1}$
}

Received: 17 March 2021 / Accepted: 29 June 2021 / Published online: 26 August 2021

(C) The Author(s) 2021

\begin{abstract}
Mosaic glass tesserae were imported to Dutch sites during the Early Medieval period, probably to address the demand for coloured glass needed in ornamental bead manufacture. Although challenging, because of the uncertainty of the material's context, the Wierum Early Medieval collection represents an extraordinary opportunity, being the most significant find of glass tesserae in the Netherlands to date. The combined use of electron microprobe analysis (EMPA) and hand-held X-ray fluorescence spectrometry (HH XRF) allowed us to examine glass tesserae and other vitreous samples from the site. Low levels for magnesium and potassium oxides $(<1.5 \mathrm{wt} \%)$ and the chemical components linked with the silica source, fluxes, opacifiers and chromophores are compatible with an older Roman soda-lime-silica glass production. Alumina and calcium oxide contents together with the adoption of antimony-based opacifiers are compatible with mosaic tesserae of a first to third century AD Roman tradition. We assume that these tesserae were collected during the spoliation of a lavish building and reused for glass objects produced locally. The hypothesis seems to be confirmed by the presence in the collection of tesserae still embedded in mortar, stone tesserae fragments and a rounded fragment of Egyptian blue.
\end{abstract}

Keywords Glass $\cdot$ Tesserae $\cdot$ Chemical composition $\cdot$ Early Medieval $\cdot$ Netherlands $\cdot$ Reuse $\cdot$ Beads

\section{Introduction}

\section{Mosaic tesserae recycling in medieval glassmaking in Northwestern Europe}

Significant numbers of mosaic glass tesserae were brought into Scandinavia and the Low Countries during the Early Medieval period (eighth to ninth centuries; Henderson et al. 2019). Evidence from several archaeological sites indicates

Hans Huisman

hans.huisman@rug.nl

1 Groningen Institute of Archaeology, Faculty of Arts, Groningen University, Poststraat 2, 9712, ER Groningen, The Netherlands

2 Dipartimento di Scienze dell'Antichità, Sapienza Università di Roma, Piazzale Aldo Moro 5, 00185 Roma, Italy

3 Cultural Heritage Agency of the Netherlands, P.O. Box 1600, 3800, BP Amersfoort, The Netherlands

4 Department of Classics and Archaeology, School of Humanities, University of Nottingham, University Park, Nottingham NG7 2RD, UK that these tesserae were probably imported to address the demand for coloured glass to produce decorated glass beads. Sites with evidence for glass bead production often also have indications that other materials were worked, including amber (Henderson et al. 2019). The number of glass tesserae from Early Medieval archaeological sites in the Netherlands is low compared to Scandinavian sites. The recent reappearance of an collection (first mentioned by Arbman in 1937) consisting of hundreds of glass tesserae from the terp settlement of Wierum in the Dutch province of Groningen (Figs. 1;2) is therefore an exception, forming the largest find of glass tesserae in the Netherlands to date (Henderson et al. 2019). Although the (direct) context of this find is unknown, it is possible to interpret the collection in the light of what is known about the history of the terp.

A tessera (pl. tesserae) is usually in the shape of a small cube, employed in mosaic production (Verità et al. 2009). A variety of materials has been adopted in antiquity for tesserae production but, while the use of stone is frequently related to floor decorations, glass tesserae were mostly applied to vaults and walls. Their origin may lie in the increasing use of glass in early Roman wall mosaics (glass vessel fragments, glass discs and glass rods), which continued until glass tesserae proper 
Fig. 1 Part of the tesserae found in the terp of Wierum, showing abrasion and rounded edges. Collection no. G 2008-III.20. Photo Northern Archaeological Depot, Nuis.

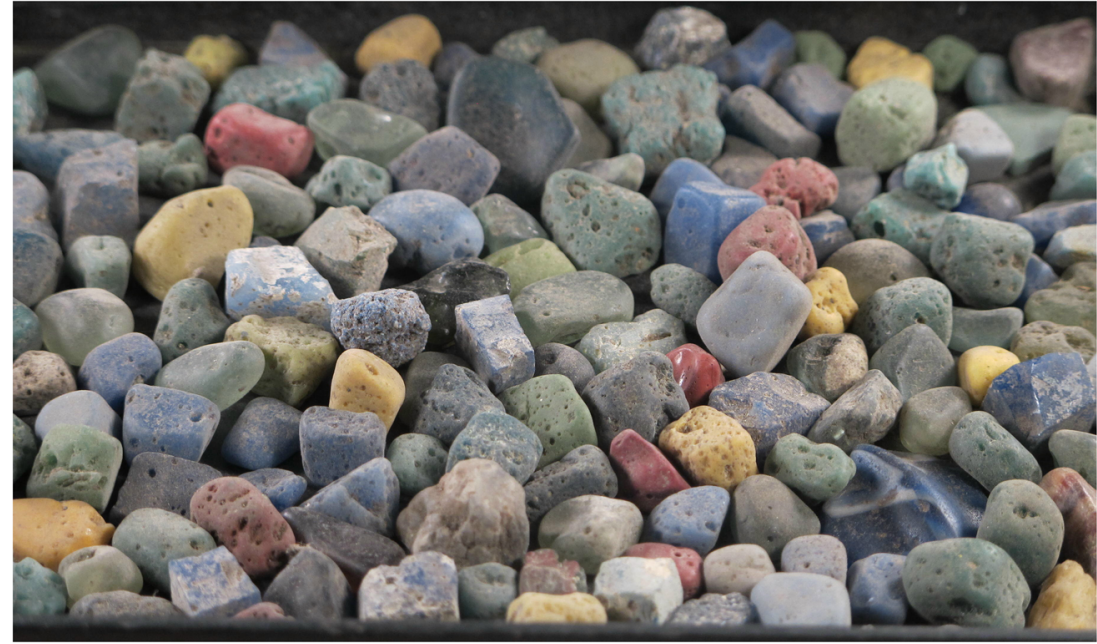

were employed exclusively (Boschetti 2011). The use of glass tesserae in wall mosaics occurred in the first half of the first century $\mathrm{AD}$, and they became frequent only from the middle of the first century AD (Sear 1977; Boschetti et al. 2012, 2016). The tradition of decorating vertical surfaces with glass mosaics probably had an origin that was separate from that of floor mosaics and was substantially a Roman invention (Sear 1977; Dunbabin 1999). It is likely that they were broken off glass sheets or 'cakes' that were made specifically for the manufacture of tesserae (Sear 1977).

\section{Glass production in the first millennium AD}

From the Iron Age until Carolingian times, Mediterranean soda-lime-silica glass was the main type used in Europe. Sand was the silica source, while evaporitic soda (natron) was employed as a flux (Rehren and Freestone 2015; Scott and Degryse 2014; Stern and Gerber 2004). The provenance of the sand exploited in Roman and Early Medieval glassmaking is, in some cases, still an open question (Brems et al. 2012). The inorganic soda was natron, a relatively pure mineral source of sodium carbonate that contains low levels of potassium oxide and magnesia. This was probably sourced in Egypt at Wadi Natrun (Henderson 2013; Rehren and Freestone 2015). Shells or limestone provided lime for stabilising the glass (Freestone 2005). From the later part of the first millennium onwards, wood and plant ashes were used as the principal fluxes in continental Europe, substituting for natron (Stern and Gerber 2004).

Primary glass making occurred in large primary tank furnaces in the Middle East (Picon and Vichy 2003). After the raw glass was produced, chunks were exported to be worked in secondary production sites in the Middle East and the West, though some was also remelted at primary production sites, such as at Jalame (Phelps and Freestone 2016). During this secondary production stage, the raw unworked glass was shaped to form various objects such as vessels (Freestone et al. 2000). Decolouring of the glass probably occurred at the primary production site (Freestone 2015), although additional opacity and colour modifications may have occurred at secondary sites (Freestone 2008; Henderson 2013). For Roman glasses, antimony and manganese were used as decolourisers between the first and fourth centuries $\mathrm{AD}$ (Jackson and Paynter 2016). Between the end of the third and the beginning of the fourth century AD, the use of manganese increased and probably gradually substituted for antimony in Roman glass production (Maltoni et al. 2016; Jackson and Paynter 2016).

\section{Antique glass colouring techniques}

Colour and opacity are the two most relevant parameters which characterise glass tesserae. The production of glass with these properties represented a challenge in antiquity since it required extensive knowledge about the colourants and base materials, the recipes and careful control of the furnace temperature and atmosphere (Arletti et al. 2006; Freestone and Stapleton 2015; Henderson 1991). In ancient glass in the west, opaque colours were mainly obtained using a combination of antimony or tin with calcium or lead respectively (calcium and lead antimonate), tin by itself or combined with lead (lead stannate). Roman yellow and white tesserae were opacified using antimony until the fourth century $\mathrm{AD}$, when tin opacifiers start to replace it, probably as a response to difficulties in retrieving antimony (Mass et al. 1998; Tite et al. 2008). Nevertheless, the picture is more complex since tin opacifiers made their first appearance as early as the sixth to seventh century BC (Purowski et al. 2012) and became more popular in the second century BC in northern Europe (Henderson 1985; Tite et al. 2008). Moreover, studies reveal the possibility that the opacifier was already used earlier, in the Roman period (Verità et al. 2013). Opacity and colour for Roman white 
glasses were obtained through variable amounts of calcium antimonate crystals $\left(\mathrm{Ca}_{2} \mathrm{Sb}_{2} \mathrm{O}_{7}\right.$ or $\left.\mathrm{CaSb}_{2} \mathrm{O}_{6}\right)$ presumably with an "in situ" crystallisation (Lahlil et al. 2010). The source of antimony is unclear: it may either have been natural stibnite $\left(\mathrm{Sb}_{2} \mathrm{~S}_{3}\right)$ or roasted stibnite $\left(\mathrm{Sb}_{2} \mathrm{O}_{3}\right.$ and $\left.\mathrm{Sb}_{2} \mathrm{O}_{4}\right)$ (Silvestri et al. 2012). Calcium antimonate compounds characterise turquoise and blue glass, in combination with copper or cobalt, respectively. Lead antimonate was used to produce a yellow opaque glass and, combined with copper, to create bright opaque green hues. The prevalent interpretation is one of the synthesis of lead antimonate crystals and its further addition to a transparent glass in the form of a powder (Boschetti et al. 2016a; Shortland 2002; Verità et al. 2013) though the use of bindheimite $\left(\mathrm{Pb}_{2} \mathrm{Sb}_{2} \mathrm{O}_{6}(\mathrm{O}, \mathrm{OH})\right)$ cannot be ruled out completely (Henderson 1985). In the former case, the colourant would have been prepared using an excess of lead, and the duration and temperature of the procedure was limited to preserve the yellow tint that would have quickly dissipated in favour of an undesired white colour (Paynter et al. 2015). Red opaque glass represents one of the most challenging recipes since it owes both opacity and colour to the presence of copper metal or copper oxide (cuprite) formed under reducing conditions (Brill and Cahill 1988; Freestone 1987; Freestone et al. 2003). The copper and lead contents may influence the precipitation of a copper rich phase and the number and size of crystals (Silvestri et al. 2014). During the first millennium BC and the Roman period, red opaque glasses are prepared mainly in two technological variants (Boschetti et al. 2016a; Freestone et al. 2003; van der Werf et al. 2009). Among the two types of red tesserae, one is characterised by a 'sealing-wax red' linked with well-developed cuprous oxide dendrites, distinguished by high lead and high copper content $\left(\mathrm{Cu}_{2} \mathrm{O}>5 \mathrm{wt} \%\right.$ and $\mathrm{PbO}>$ $15 \mathrm{wt} \%)$. The sealing wax red dates to between the eighth century $\mathrm{BC}$ to the first century $\mathrm{AD}$; it is then replaced by a dullish red opaque glass until the fourth early fifth century $\mathrm{AD}$ (Boschetti et al. 2016a). Another type known as "rubyred glass", usually bears a sub-micron particulate distribution of copper with a significantly lower content of lead and metallic copper (van der Werf et al. 2009) and is translucent/dichroic. A further important compositional characteristic of dull opaque red tesserae is their elevated levels of magnesium and potassium oxides (Henderson 1991; Schibille et al. 2012) showing that plant or wood ashes were involved in their production; see below.

\section{Recycling and reuse}

The earliest evidence for recycling glass tesserae is from the Domus Delle Bestie Ferite in Aquilea, Italy (Boschetti and Leonelli 2016). Built in the late first c. BC and early first c. $\mathrm{AD}$, this upper-class house was radically modified and expanded in the fourth century and was abandoned in the fifth century, a period of political and economic decline. During the fourth century, a beadmaking workshop was installed in a probable reception room in the old core of the house. Glassworking was based on recycling of tesserae and window glass for the production of glass beads and ornaments.

In the sixth to seventh century AD during a destruction phase of the Roman villa of Aiano-Torraccia in Tuscany (Cavalieri and Giumlia-Mair 2009), a comparable workshop was installed in which glass fragments and tesserae collected in the ruined building were remelted and, e.g. used for beadmaking. An overview by Munro (2020) indicates that during the Late Antique and Early Medieval period, Roman buildings were substantially used as "mines" with the buildings stripped of their stone, metal and glass. Stone was used as spolia or (in the case of limestone and marble) burnt in kilns to produce lime for mortar. Metals and - in some cases - glass were remelted in dedicated installations on site (Munro 2020). This evidence for on-site recycling during the dismantling of Roman buildings, however, does not provide an indication as to what extent glass (and metals) were being collected and transported or traded to other locations as raw materials for recycling. It is remarkable that as late as the twelfth century AD, Theophilus Presbyter in "De Diversis Artibus" II, XXII describes the remelting of mosaic glass, collected from ancient "pagan" buildings, to colour window glass and enamelled metalwork (Theophilus Presbyter 1987). He indicates that glass tesserae were transported to countries north of the Alps, where fewer mosaics from abandoned Roman villas were present.

In the Netherlands, tesserae almost exclusively appear in the Carolingian period. No tesserae were found on three Merovingian settlements with ample evidence for beadmaking (Sablerolles et. al.1997; Sablerolles 1999; Dijkstra et al. 2010). In Carolingian settlements along and north of the Rhine, they are associated with beadmaking. Until the Wierum find came to light, most tesserae were known from Dorestad, where there is evidence for the practice of recycling tesserae in the form of a crucible with the remains of a melted opaque white tesserae in a translucent pale greenish base glass (Preiß 2010). Fragments of glass discs or cakes and partially melted scrap vessel glass were another source of 'raw' glass at Dorestad. Single tessera finds in the Netherlands come from settlements along and north of the Rhine (Henderson et al. 2019), including one from the Frisian terp site at Wijnaldum, where a yellow tessera and a fragment of punty glass from a beadmaker's tool in an eighth-century context point to beadmaking in the Carolingian period (Sablerolles 1999). The paucity of the material suggests temporary workshops set up by travelling beadmakers, perhaps based at Dorestad, rather than the establishment of permanent workshops.

The model of itinerant beadmakers in the Early Medieval period Northwestern Europe is not a new one (Callmer 1997; Dijkstra et al. 2010). During beadmaking experiments at Ribe, Denmark, Risom (2013) has shown that a simple, small 
'volcano' beadmaking furnace can be made from clay in just 1 day. This type of furnace excludes the use of crucibles, which could explain the paucity of crucible finds on eighth to ninth century beadmaking sites. Tesserae would have been softened on an iron pan, such as one found among bead production waste at Ribe, picked up with a punty and directly worked into beads above the furnace from where the concentrated heat emanated. Even a more elaborate, domed structure, such as the reconstructed Merovingian beadmaking furnace at Rijnsburg (Dijkstra et al. 2010) would not have taken very long to make.

The experimental beadmaker Sue Heaser (2018) calculated that only about $50 \mathrm{~g}$ of raw glass is needed to make a $45-\mathrm{cm}$ long necklace, depending on the size of the beads. As Carolingian beads of the second half of the eighth and early ninth centuries are relatively small monochrome or simply trailed types (Callmer 1997; Sablerolles and Henderson 2012), this means just $1 \mathrm{~kg}$ of glass would have been sufficient to make enough beads for 20 necklaces. If we take the average weight of a tessera as $1.5 \mathrm{~g}$ (James 2017), around 670 tesserae would have been sufficient to make enough beads for 20 necklaces. A travelling beadmaker carrying several kilos of tesserae, a small amount of 'raw' glass discs and some scrap vessel glass would therefore have been able to supply the inhabitants of several settlements with beads.

\section{The socio-political context of the site}

The coastal area of the northern Netherlands was a frequently flooded salt marsh area until embankments were constructed from the eleventh/twelfth century (Fig. 2A). People built their houses on terps, artificial dwelling mounds that provided protection against floods. Although the salt marshes saw frequent flooding and erosion/sedimentation processes, the terp mounds themselves have been shown to provide an excellent environment for the preservation for vulnerable archaeological remains (Nieuwhof et al. 2019).

Despite the extreme natural conditions, the area was quite densely populated; during the Early Medieval period, there may have been as many as 1500 inhabited terps in the present provinces of Groningen and Friesland (Nieuwhof 2015). Animal husbandry (especially cattle and sheep) was the basis of the economy, but arable farming was also practiced (Schepers 2016; Nicolay and de Langen in press). The salt marsh was part of a maritime landscape, which connected the terp settlements over water with the wider world: the coastal areas bordering the North Sea, and the Dutch central river area and the Rhineland to the south. Many finds show that the northern Netherlands participated in social networks connecting these areas (Nieuwhof et al. 2020).

Most of the basic necessities of life were produced at home, for domestic use. That applies to food, textiles, pottery and probably also metalwork. Throughout the Roman period there is no evidence of political centralisation in this area. That changed after the fourth century habitation hiatus in the northern Netherlands. A new population formed, mainly consisting of migrants from northwestern Germany and possibly southern Jutland, and a more stratified society emerged (Nieuwhof et al. 2020). Between AD 550 and 650, the area surrounding Wijnaldum, northern Westergo, had developed into the centre of a kingdom that covered the entire terp region of the northern Netherlands. The distribution of gold jewellery in a distinctive style suggests that the king residing at or near Wijnaldum had retainers in this entire area (Nicolay 2014: 20-23). The find of a crescent-shaped gold pendant at Wierum suggests that one of these retainers, a local leader, lived here (Nicolay 2014).

Excavations at Wijnaldum did not reveal a royal residence, but they did produce an artisanal area with evidence of gold and silver smithing, which must have been a specialised activity under the patronage of the king. Evidence of glass bead production, however, was sparse, and this craft may have been combined with another high temperature craft such as metal working (Sablerolles 1999). The political centre seems to have controlled the import of goods such as Merovingian coarse ware and biconical fine ware from the Frankish realm, since Merovingian wheel-thrown pottery is distributed in a pattern that is rather similar to the distribution of gold jewellery: most concentrated near the centre with a diminishing number of vessels further away (Nieuwhof et al. 2020).

That all changed in the Carolingian period. During the eighth century, the northern Netherlands was incorporated into the Frankish empire (present-day Friesland in 734, Groningen in 784 AD), and northern Westergo was no longer the political centre controlling the entire area. Imported Carolingian pottery seems to be more evenly distributed across the northern coastal area, indicating that individual traders may now have had access to the area unobstructed by the demands of a political centre (Nieuwhof et al. 2020).

\section{The context of the finds}

The terp of Wierum, a semi-spherical site of c. 5 ha was located on the wide river Hunze (later named Reitdiep), which connected the Wadden Sea and North Sea with the interior of the land (Fig. 2B). As was typical of the way in which terps were treated between c. 1840 and 1950, soil from Wierum was quarried for use as fertiliser and soil improvement between 1912 and 1916 (Nieuwhof 2006). The soil was shipped inland via the small harbour of Wierumerschouw on the nearby river Reitdiep, and therefore nearly all the finds that were collected from the excavated soil were recorded under the name of Wierumerschouw, rather than Wierum itself. Only $c .1 .5$ ha of the original wierde (mound) remained (see Fig. 2B). In addition to the results of a coring programme, that provided information on the original circumference and the subsoil of 

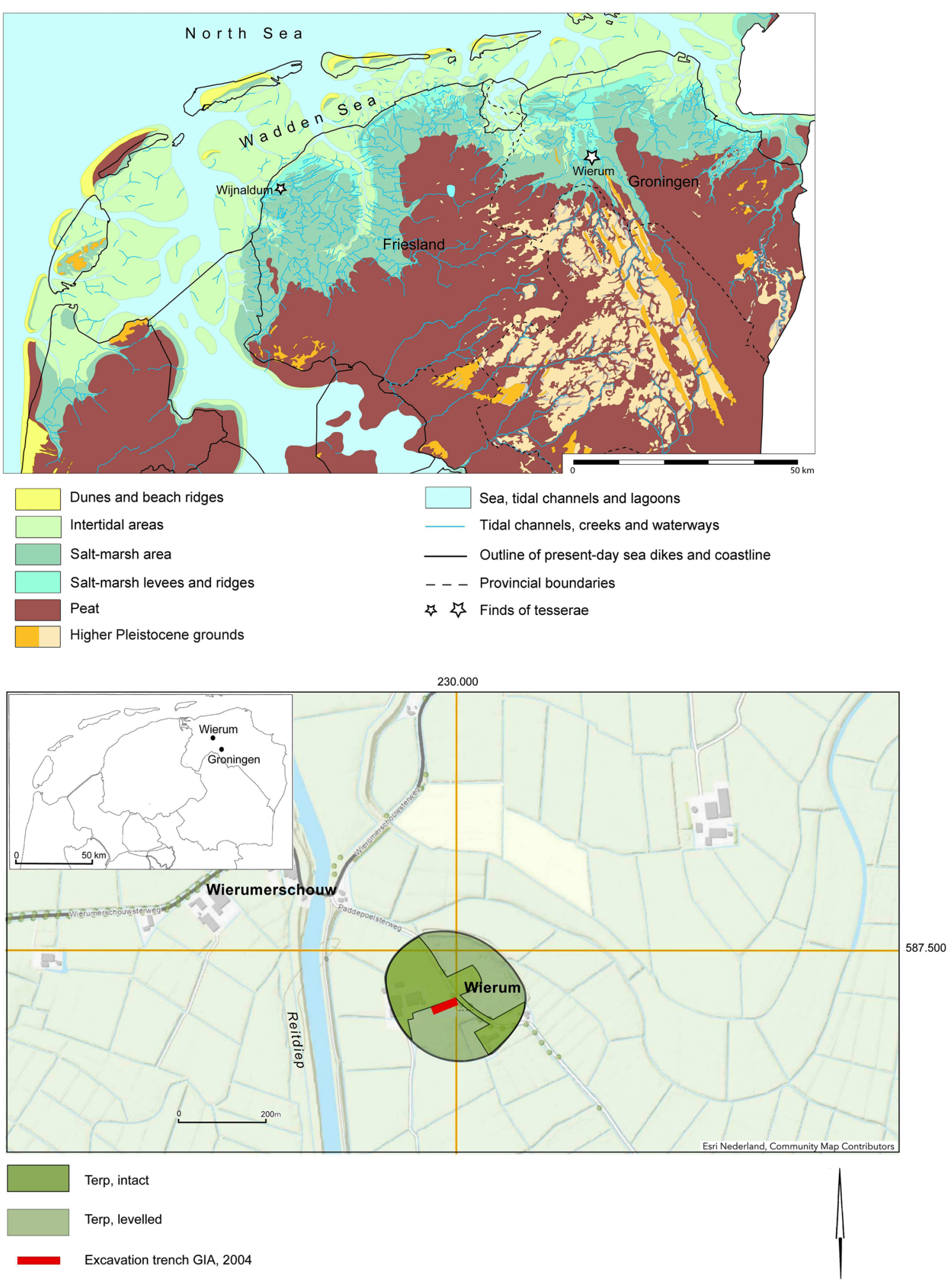

Fig. 2 Site information: A Paleogeographic map of the northern Netherlands (the situation of c. AD 800) with the find locations of tesserae. Basic map P.C. Vos and S. de Vries, Deltares, locations and toponyms are added by A. Nieuwhof. B Topographical map with Wierum and its direct environment. The original circumference of the terp with intact and quarried parts are indicated, as well as RD coordinates (RD 230000//587500 equals to DMS N 53.16'7580//E 6.30'4089). The original meandering course of the Hunze/Reitdiep river is still visible in the field boundaries north of the terp. Base map ESRI Nederland. Details added by A. Nieuwhof 
the terp, in 1983 an overview of the finds was published (Miedema 1983). Archaeological excavations were only conducted in 2004, when the province of Groningen decided to restore the terp to its original size and shape using dredged soil from the river Reitdiep (Nieuwhof 2006; Fijma 2008). The excavations determined that the site was inhabited from the fourth century BC or slightly earlier, until at least the Late Middle Ages, probably with an interruption in the fourth century AD (Fijma 2008; Nieuwhof 2006, 2011). Unfortunately, farmhouses and outbuildings or artisanal areas have not been excavated. However, like all terps, Wierum must have been a mainly agricultural and self-sufficient settlement throughout most of its existence, without much labour specialisation (for animal husbandry, see Prummel 2006).

The northern Netherlands belonged to the Roman Empire for only a short period, between $12 \mathrm{BC}$ and $\mathrm{AD}$ 47. After the limes was established at the river Rhine in the central River area, there were still contacts with the Romans, especially in the second and third centuries, as is shown by $c$. twenty second to third century terra sigillata sherds found by commercial digging (Glasbergen 1944). While these objects may have been imported during the Roman Period (on the use of terra sigillata, see Nieuwhof 2020), the tesserae probably arrived later, after the habitation hiatus, during the Early Middle Ages. If we take other finds of tesserae in the Netherlands and Scandinavia as a guide (Henderson et al. 2019), a date in the Carolingian period seems most likely. During the excavation of 2004, the only glass recovered at the site was a yellow-red glass bead, retrieved from a layer dated to the sixth to seventh century AD (Nieuwhof 2006).

The Wierum collection comprises 241 objects or fragments and is stored at the archaeological depot of the northern provinces in Nuis (collection NAD nos. G 2008-III.20 and 21). The scant available documentation indicates that it was found in 1916 during commercial quarrying.

Unfortunately, more precise information about the context of the find material is not available, nor is it known how the glass an other materials were collected. Hand-picking is the most likely method, as commercial mining of the terps was entirely done by workers with shovels, but wet screening of some of the soil, once it was discovered that it contained colourful little stones, cannot be excluded. A tourist brochure from 1916 recommended visiting the commercial excavation in order to search for old objects, or to buy a memento from the workers (Knol 1996). That implies that the workers may have actively searched for interesting objects to raise their income. The acquisition history indicates that the collection is probably not complete, and that it may also include objects that do not originally belong to it. That certainly applies to one (sub-) recent colourless, weathered glass vessel fragment with the same collection number.

\section{The present study}

Here, we present the results of chemical analyses carried out on a selection of glass tesserae and other glass materials from the Wierum terp. The chemical analyses provide answers to questions concerning the provenance and production date of the tesserae, and their reuse in the production of glass artefacts, especially beads. Moreover, we will discuss how this collection fits with what we know about the Early Medieval history of the area in which it was found.

\section{Materials and method}

\section{The material}

The vast majority of the objects in the collection is made of glass. However, in a first presentation of this collection, Henderson et al. (2019) already indicated that non-glass objects were present in the collection (Table 1). Closer inspection showed the presence of several stone tesserae in the assemble, including two of green and one of red porphyry (Fig. 3.1-2). A complete white stone tesserae, presumably made of marble, is still embedded in mortar (Fig. 3.3). Two basalt lava fragments must have been imported (Fig. 3.4), since the nearest volcanic region (Eiffel, Germany) is hundreds of kilometres from the site. Basalt lava quernstones and Roman spolia of volcanic rock are known from Early Medieval sites in the Netherlands, so it is unclear whether these fragments have the same source as the rest of the collection or are intrusive. Two quartz fragments and four pebbles may or may not form part of the original material.

Moreover, a fragment of mortar, two fragments of amber (Fig. 3.6) and a rounded fragment of Egyptian blue (Fig. 3.5) are included (Table 1). These are not included in this compositional study.

Table. 1 Overview of the Wierum material

\begin{tabular}{ll}
\hline Category & Number \\
\hline Glass objects (N=224) & \\
Tesserae (complete, fragmentary, heat-affected) & 201 \\
Roman vessel glass & 5 \\
Roman or Early Medieval vessel glass & 1 \\
Postmedieval vessel glass (borate?) & 1 \\
Drops & 16 \\
Others (N=17) & \\
Stones, including 3 stone tesserae & 12 \\
Mortar fragment & 1 \\
Egyptian blue fragment & 1 \\
Amber fragments & 2 \\
Total & 240 \\
\hline
\end{tabular}




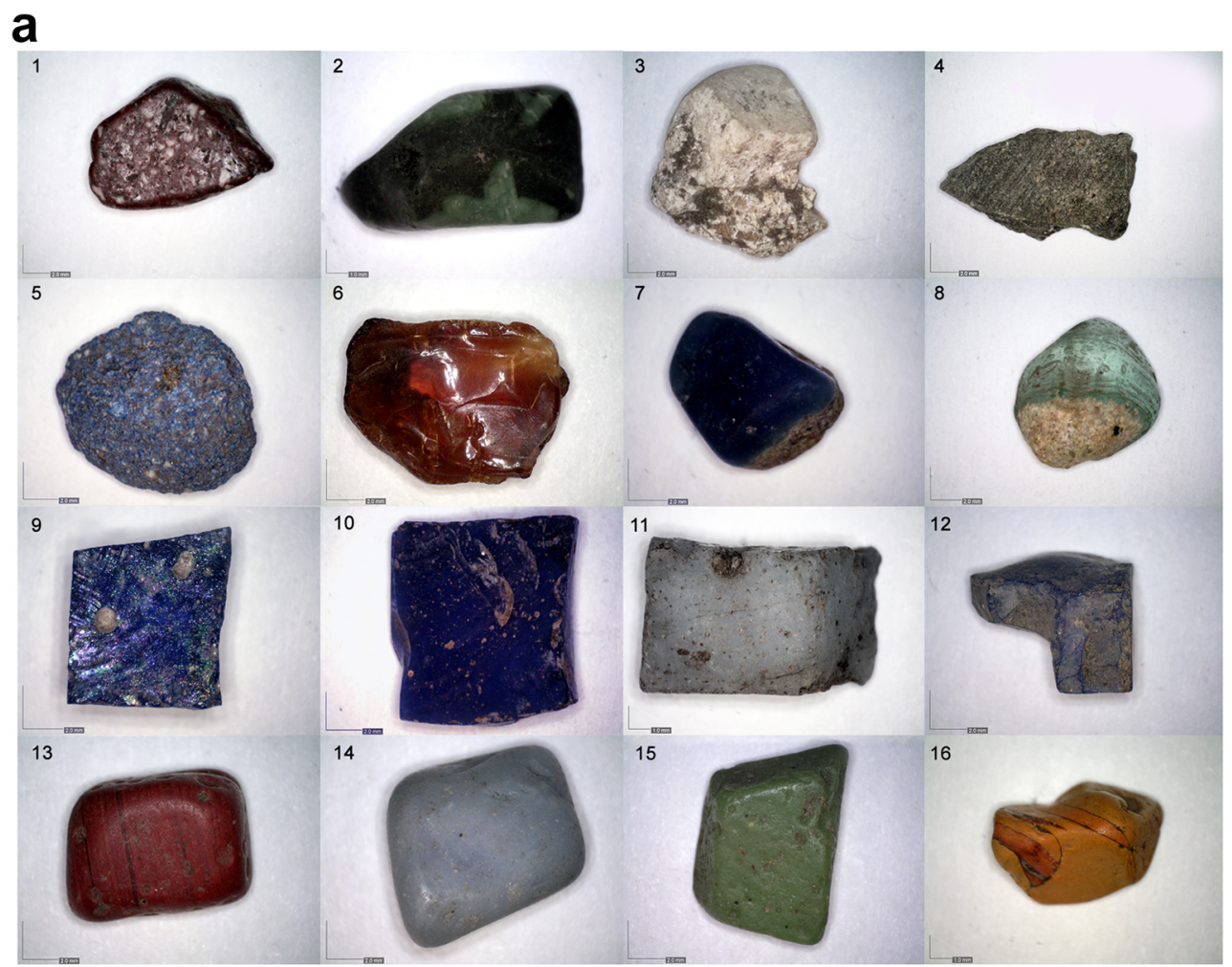

Fig. 3 A selection of samples from the Wierum collection. 1: a red porphyry fragment; 2 : a green porphyry fragment; 3 : a white stone tessera (possibly marble) embedded in mortar; 4: a basalt fragment; 5 : a rounded Egyptian Blue fragment; 6: an amber fragment; 7: w202, a blue transparent glass tessera with mortar adhering; 8: w253, an aqua transparent glass tessera with mortar adhering; 9: w45, a bright blue opaque tessera with sharp angles intact; 10: w518, a bright blue opaque tessera with sharp angles intact; 11: w51, a fragmented white-grey opaque tessera with sharp angles intact; 12: w60, a fragmented blue opaque tessera; 13: w20, a heat-affected red opaque tessera; 14: w25, a heataffected milky-blue opaque tessera; 15: w10, a heat-affected bright green opaque tessera; 16: w50, a heat-affected opaque orange tessera showing banding with opaque red glass; 17: w112, a lump of yellow-green opaque glass; 18: w104, a lump of yellow opaque glass; 19: w100, a lump of red opaque glass; 20: w139, a lump of bright green opaque glass; 21: w52, a drop of bright green opaque glass; 22: 36, a drop of blue transparent glass; 23: w34, a drop of colourless glass; 24: w237, a drop of naturally coloured greenish glass with dark streaks; 25 : w31, a fragment of an early Roman ribbed bowl of transparent blue glass marbled with opaque white glass; 26: w32, a fragment of an opaque pale grey-green early Roman bowl or dish, probably moulded; 27; w33; a lump of melted transparent amethyst purple glass, most likely from an early Roman glass vessel; 28: w91, a transparent turquoise fragment of an early Roman moulded vessel with traces of wheel-polishing on the inside
The tesserae $(n=201)$ show a wide variety of colours and tints and range from opaque to transparent or semi-translucent (Table 2). Most of glass samples, included in this study, appear to be strongly affected by heat, whereas some show evidence of abrasion. There are only 32 tessera samples that still retain their typical angular appearance: a cubic or cuboid shape with sharp angles (Figs. 3.9, 10).

The Wierum collection appears to present several stages in an ongoing heat-treatment or partial re-melting of glass tesserae. This process also includes a step consisting of partial fragmentation of the tessera with the possible final aim of speeding up the glass remelting. This is clearly visible in some highly fragmented tesserae (Fig. 3.11, 12). The link between the tesserae and these heat-affected glass objects is shown by some samples that still bear an angular appearance but also have edges rounded by heat giving them a semi-melted appearance (Fig. 3.13-15). An opaque orange tessera with opaque red banding is both fragmented and partially melted (Fig. 3.16). The collection also includes lumps of opaque coloured glass that completely lack sharp edges or geometric shapes which seem to be deformed tesserae (Fig. 3.17-20).

A couple of tesserae (w 202, w253) have obvious limebased cement or plaster sticking to them (Fig. 3.7, 8), while on others only whitish traces remain (w254, w256). Therefore, the mortar fragment mentioned above most likely comes from a tessera. One fragment of weakly coloured transparent glass (w250) adhered to a chunk of ceramic material, probably a fragment of a crucible. However, more detailed study is needed to ascertain this; the fragment has been heavily abraded as well. Therefore, sample w250 will be not included in this study.

A small number of fragments derive from glass vessels ( $n=$ 6). A body fragment with part of a rib is of a blue and white marbled ribbed bowl of the first half of the first century $\mathrm{AD}$ 
b

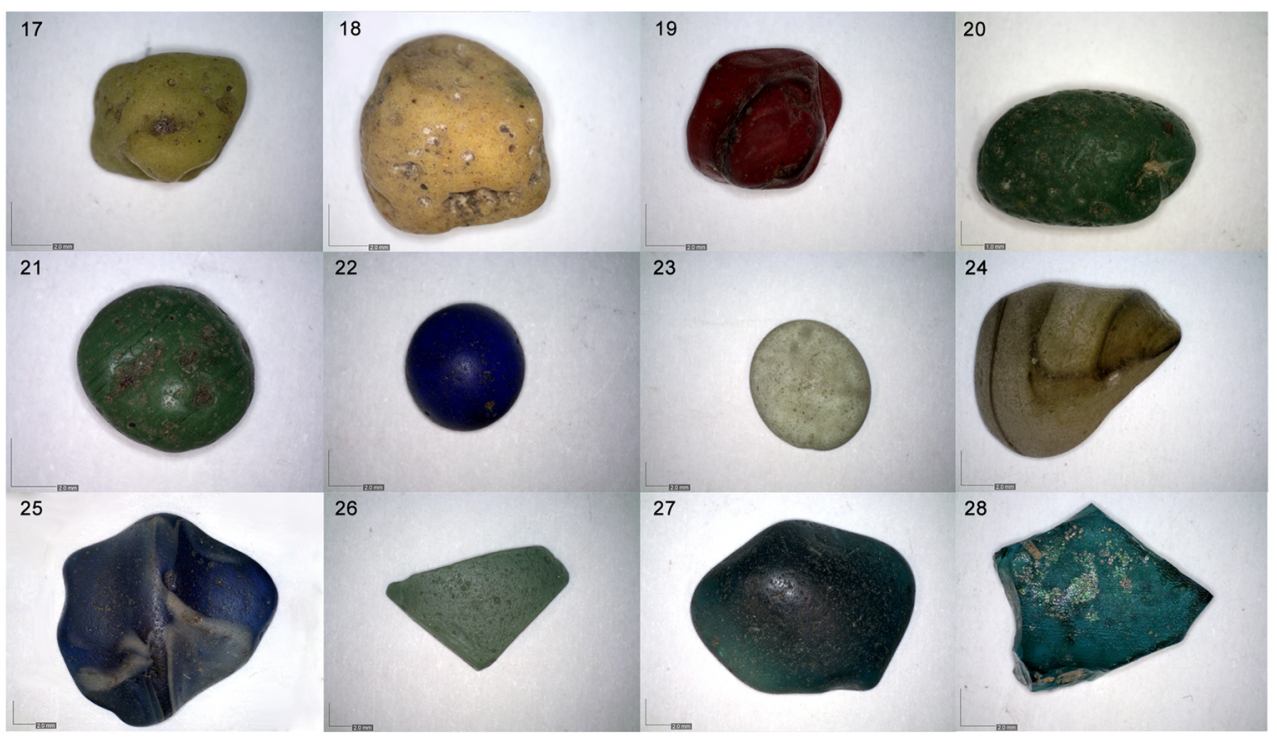

(Fig. 3.25). An opaque pale greyish green body fragment and a transparent turquoise body fragment most likely derive from early Roman moulded bowls or dishes (Fig. 3.26). On the iridescent inside of the latter, traces of wheel-polishing are visible. Two heat-affected transparent turquoise and amethyst purple fragments are most likely of early Roman vessels too; purple being especially rare in the Early Medieval period (Fig. 3.27). A partially melted body fragment of naturally coloured greenish glass with two self-coloured trails may be of a Roman or an Early Medieval vessel.

The group of drops $(n=16)$ mainly consists of weakly coloured transparent glass characterised by different shapes (mostly plano-convex), dimensions and shades of colours (colourless, aqua transparent and green transparent). Among these are two plano-convex transparent dark blue (w36) and opaque bright green (w52) examples (Fig. 3.21-23). The latter has a small indent in the curved surface, possibly an imprint of a tool such as a spatula (cf. Boschetti and Leonelli 2016).

It is unclear what caused the abrasion that can be seen on some of the fragments (e.g. w250). Possible explanations may be erosion processes in the source area of the tesserae, erosion processes in the surroundings of the terp site proper or mechanical damage during extraction or sieving.

\section{Compositional analyses}

All 223 glass objects were analysed with a Niton hand-held (HH) XRF. Analyses of the non-glassy material are not included in this study.

XRF analyses were done following the procedure described in Huisman et al. (2017) with a Thermo Scientific Niton XL3t energy-dispersive hand-held XRF analyser, equipped with a silicon drift detector, using a portable test stand. The irregular shapes of the objects posed a specific challenge for these analyses, and a sample position was chosen so as to analyse an area that was as flat as possible using the in-built camera in the XRF machine. The $\mathrm{Cu} / \mathrm{Zn}$-mining mode was used, with a measuring time of $110 \mathrm{~s}$, using 4 sequential energy settings: light range $(\mathrm{Mg}$ to $\mathrm{Cl})$ at $8 \mathrm{kV}$ $200 \mathrm{~mA}$, low range (K to Ti) at $20 \mathrm{kV} 100 \mathrm{~mA}$, main range ( $\mathrm{V}$ to $\mathrm{Ag}$ including L-lines for $\mathrm{Pb}$ ) and high range (Cd-Ba) both at $50 \mathrm{kV}, 40 \mathrm{~mA}$. Detection limits are determined automatically during measurement and are defined as 3 times the standard deviation of the background. As the background may vary between measurements because of matrix effects, the detection limit may vary between analyses. Analyses with concentrations below this detection limit were automatically set to " 0 ". After the measurements, XRF Spectra were checked individually by eye to evaluate potential peak overlaps.

Since the use of factory calibrations is a potential source of error they were checked with a set of 14 samples (powdered soils) from the round-robin tests of the International Soil Exchange (ISE) programme (samples 889, 909, 910, 921, 930, 952,958, 962, 970, 986, 989,995, 998 and 999; see also Huisman et al. 2017). Based on these results, the measurement results of the glass were adjusted post hoc for some of the elements. Accuracy was tested with the BAMS005B standard; see Online Resource 1. The full results of the HH XRF analyses can be found in Online Resource 2.

For EMPA analyses, a selection of objects was made which was as representative as possible for the different groups of glass observed in the XRF analyses. Small fragments were chipped off the selected glass objects and analysed following 
the methods described in Henderson et al. (2016). The samples were mounted in cold-setting epoxy resin, and then were ground and polished using standard sample preparation procedures down to a $0.02-\mu \mathrm{m}$ final polishing solution. The samples were coated with a thin film of carbon of $25 \mu \mathrm{m}$ prior to analysis, to allow the conduction of the electron beam and to prevent its distortion. The polished samples were analysed by EPMA-WDS, using a JEOL JXA-8200 electron microprobe in the University of Nottingham Nanoscale and Microscale Research Centre (nmRC). Quantitative compositional analyses were carried out using the following analytical set-up: $20 \mathrm{kV}$ accelerating voltage, $50 \mathrm{nA}$ beam current and a $50-\mu \mathrm{m}$ defocused beam. The counting times were $30 \mathrm{~s}$ on the peak and $15 \mathrm{~s}$ on the background on either side of the peak. A defocused beam is used to reduce the effect of the migration of alkalis within the samples (Henderson 1988). The EPMA-WDS was calibrated against a combination of certified standard reference materials, including minerals (orthoclase, jadeite, pyrite, wollastonite and $\mathrm{MgO}$ ), pure metals

Table. 2 Colour spectrum of the Wierum glass analysed. The glass samples occur in many colours and tints, this table gives an overview of the colour spectrum of the glass objects presented in this study

\begin{tabular}{ll}
\hline Tesserae (complete, fragmented and heat-affected) & $N=200$ \\
White-grey opaque & 3 \\
Milky blue opaque & 16 \\
Blue opaque & 32 \\
Blue transparent & 20 \\
Bright green opaque & 19 \\
Dark green opaque & 35 \\
Dark green-blue opaque & 17 \\
Yellow-green opaque & 7 \\
Yellow opaque & 13 \\
Orange opaque & 1 \\
Red opaque & 8 \\
Turquoise opaque & 11 \\
Turquoise transparent & 1 \\
Weakly coloured transparent & 17 \\
..of which with cement & 5 \\
Drops & $N=16$ \\
Blue transparent & 1 \\
Bright green opaque & 1 \\
Weakly coloured transparent & 14 \\
Vessel fragments & $N=6$ \\
Marbled blue and white & 1 \\
Pale greyish green opaque & 1 \\
Turquoise transparent (heat-affected) & 1 \\
Purple transparent (molten lump) & 2 \\
Blue-green transparent (heat-affected) & 1 \\
Total & 1 \\
\hline & $17=222$ \\
\hline
\end{tabular}

(Mn, Ti, $\mathrm{Cu}, \mathrm{Ag}, \mathrm{V}, \mathrm{Sb}, \mathrm{Zn}, \mathrm{Sn}, \mathrm{Ni}, \mathrm{Co} ., \mathrm{Cr}$ and $\mathrm{Zr}$ ) and synthetic standards ( $\mathrm{PbTe}, \mathrm{GaP}, \mathrm{InAs}, \mathrm{KCl}, \mathrm{BaF}$ and $\mathrm{SrF}$ ), and was corrected using the phi-rho-z model. The compositions of 23 elements were sought and were expressed as weight percentage oxides. Three areas of interest on each sample were located using images produced by a backscattered detector, then they were analysed thrice and the mean and standard deviations were calculated. So as to check the accuracy and precision of the EPMA-WDS system and to monitor any drift in the instrument (Meek et al. 2012), six analyses of a secondary standard, Corning B (Brill 1999), were included during the analytical run (two sets of analyses at the start and another two sets at the end of the sample run, and another two sets of analyses half-way through the analytical run; for the results, see the table in Online Resource 3; the EPMA data is in Online Resource 4).

A total of 127 measurements from these 41 selected glass specimens are available. The EMP analyses revealed that sample w92 consisted of (sub)recent glass, so the analyses of this sample will not be considered further. Also, the sample w250 had to be removed from this study since the glass is almost completely embedded in an encrustation, which prevents a reliable analysis from being carried out.

We compared the two methods (XRF and EPMA) employed to analyse the composition of the glass tesserae from Wierum. Scatterplots of all elemental concentrations analysed with both methods are combined in Online Resource 5. In these scatterplots, a distinction is made between EPMA analyses of the base glass and those for opacifying crystals, since the chemical compositions of the opacifiers will not match the (bulk) HH XRF analyses. For four elements with wide concentration variability $(\mathrm{CaO}$, $\mathrm{Fe}_{2} \mathrm{O}_{3}, \mathrm{~Pb}, \mathrm{Sb}$ ), additional graphs were made of a specific part of the overall chart to better show the pattern. Based on these scatterplots, the results can be classified as follows:

1. Elements where the analyses of HH XRF and EPMA of base glasses in general agree well. These are: $\mathrm{CaO}, \mathrm{Cu}$, $\mathrm{Fe}_{2} \mathrm{O}_{3}, \mathrm{MnO}, \mathrm{Pb}, \mathrm{Sb}, \mathrm{Zn}$.

2. Elements where XRF analyses are influenced by surface weathering or contamination and therefore do not represent the exact concentration of the glass matrix.

3. Elements where the EPMA analyses show considerably more variability (although still within the concentration range of the $\mathrm{HH} \mathrm{XRF}$ ), which can be attributed to the heterogeneity of the base glass: $\mathrm{Co}, \mathrm{TiO}_{2}, \mathrm{~K}_{2} \mathrm{O}$ (although surface contamination during manufacture (ash) or after burial may have played a role here for the XRF results).

4. Elements with unexplained systematic higher values in one of the methods: $\mathrm{Co}, \mathrm{K}_{2} \mathrm{O}$ (although surface contamination during manufacture (ash) or after burial may have played a role here too for XRF results), Sn. 
5. Elements where the two methods do not agree well. These elements are $\mathrm{Ba}, \mathrm{Cr}$ and $\mathrm{SiO}_{2}$.

6. Elements that are only available in one of the two techniques $\left(\mathrm{Na}_{2} \mathrm{O}, \mathrm{Zr}\right)$.

Based on this comparison, we chose which elements to use for studying the base glass compositions. There was no choice for some elements as they were only available from HH XRF analyses ( $\mathrm{Sr}, \mathrm{Zr})$ or EPMA $\left(\mathrm{Na}_{2} \mathrm{O}\right)$. Other criteria were: (1) since all objects - and not just a selection - were analysed by HH XRF, these data had the preference where the two methods agreed and there were no consistent or detectable surface weathering or contamination effects. This was the case for most colourants, decolourants and opacifiers $\left(\mathrm{Cu}, \mathrm{Fe}_{2} \mathrm{O}_{3}\right.$, $\mathrm{MnO}, \mathrm{Pb}, \mathrm{Sb}$, but also $\mathrm{Co}$ ) and $\mathrm{CaO}$ (but see below). (2) EPMA analyses are preferred for elements that are influenced by surface weathering or contamination $\left(\mathrm{Na}_{2} \mathrm{O}, \mathrm{Al}_{2} \mathrm{O}_{3}, \mathrm{MgO}\right.$, $\left.\mathrm{P}_{2} \mathrm{O}_{5}\right)$ or do not agree well $\left(\mathrm{SiO}_{2}\right)$. (3) Where two elements are compared, our preference was to use the analyses of one technique to avoid bias from differences between analyses and analytical techniques (e.g. $\mathrm{CaO}$ in $\mathrm{CaO}-\mathrm{Al}_{2} \mathrm{O}_{3}$ plots). (4) The concentration of some elements is not relevant for the present investigations, and they will, therefore, not be discussed any further (Ba, $\mathrm{Cl}, \mathrm{Cr}, \mathrm{S}, \mathrm{Zn})$.

\section{Results and discussion}

\section{Base glass}

\section{The flux}

The analysed samples (tesserae, vessel fragments and glassworking refuse) are either lead-free or lead-rich sodalime-silica glasses, with $\mathrm{SiO}_{2}$ values between 47.6 and 71.8 wt $\%, \mathrm{Na}_{2} \mathrm{O}$ values between 10.8 and 18.0 wt $\%$ and $\mathrm{CaO}$ between 4.4 and $11.2 \mathrm{wt} \%$. Most specimens are characterised by low magnesia and potash concentrations (both $<1.5 \mathrm{wt} \%$; Fig. 4), which agrees with the use of natron as flux (Lilyquist and Brill 1993; Henderson 2013; Rehren and Freestone 2015).

Two red tesserae (w20 and w99; six measurements) show higher values of magnesia and potash as well as phosphorus $\left(\mathrm{P}_{2} \mathrm{O}_{5}>0.6\right.$ wt\%; Fig. 5). Similar compositions for red tesserae have been found before in antique red opaque glass and enamels (Boschetti et al. 2016a; Henderson 1991; Nenna and Gratuze 2009; Paynter et al. 2015; van der Werf et al. 2009). At first sight, such high levels of $\mathrm{MgO}$ and $\mathrm{K}_{2} \mathrm{O}$ as well as $\mathrm{P}_{2} \mathrm{O}_{5}$ could suggest the employment of plant ash as a flux (Henderson 1988; see also Boschetti et al. 2016a; van der Werf et al. 2009). The levels of magnesia and potash are still

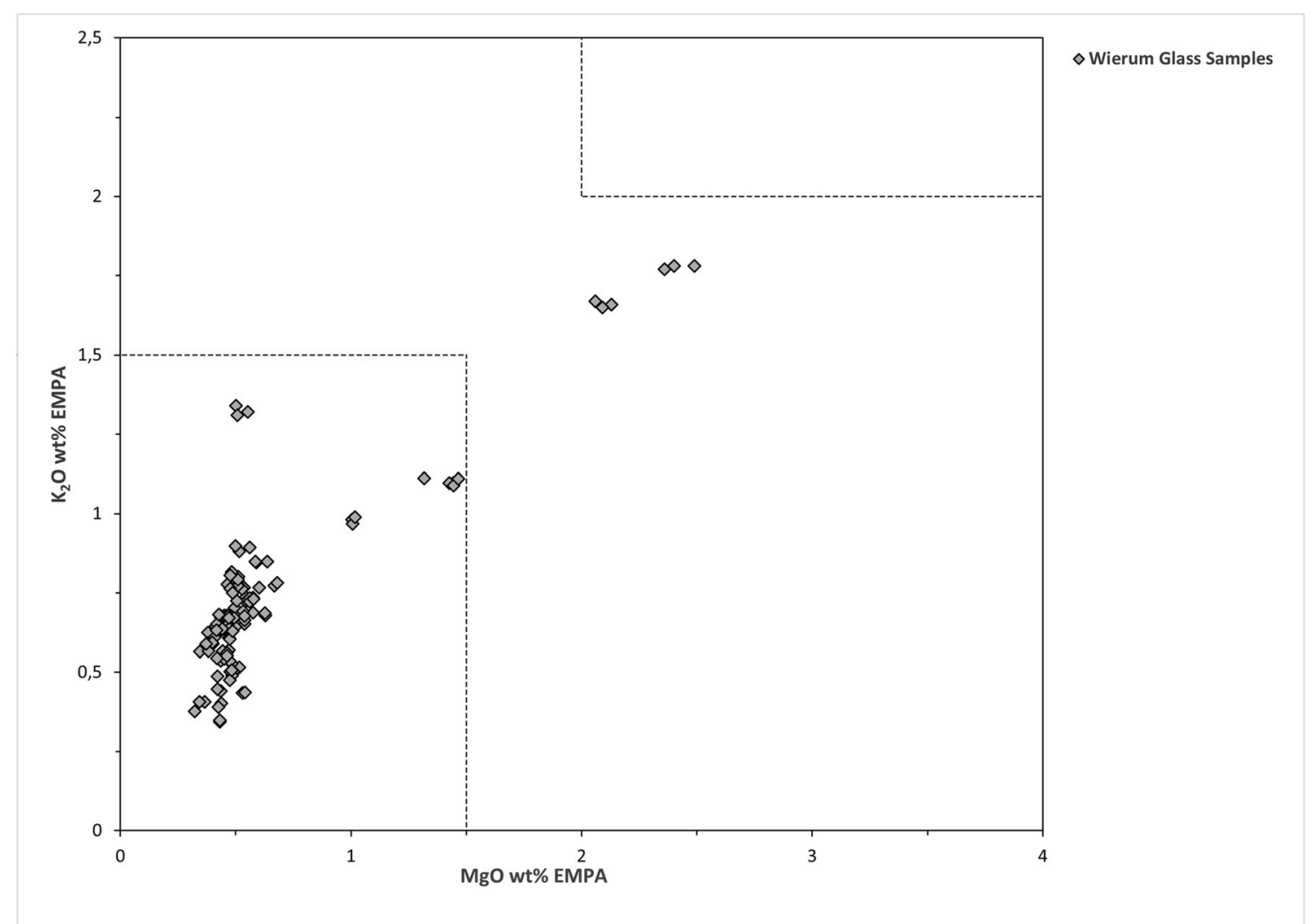

Fig. 4 Potassium oxide versus magnesium oxide concentrations (wt \%) of the analysed glasses. Dotted areas refer to glass produced using alkaline natron and plant ash fluxes, according to Lilyquist and Brill (1993). 


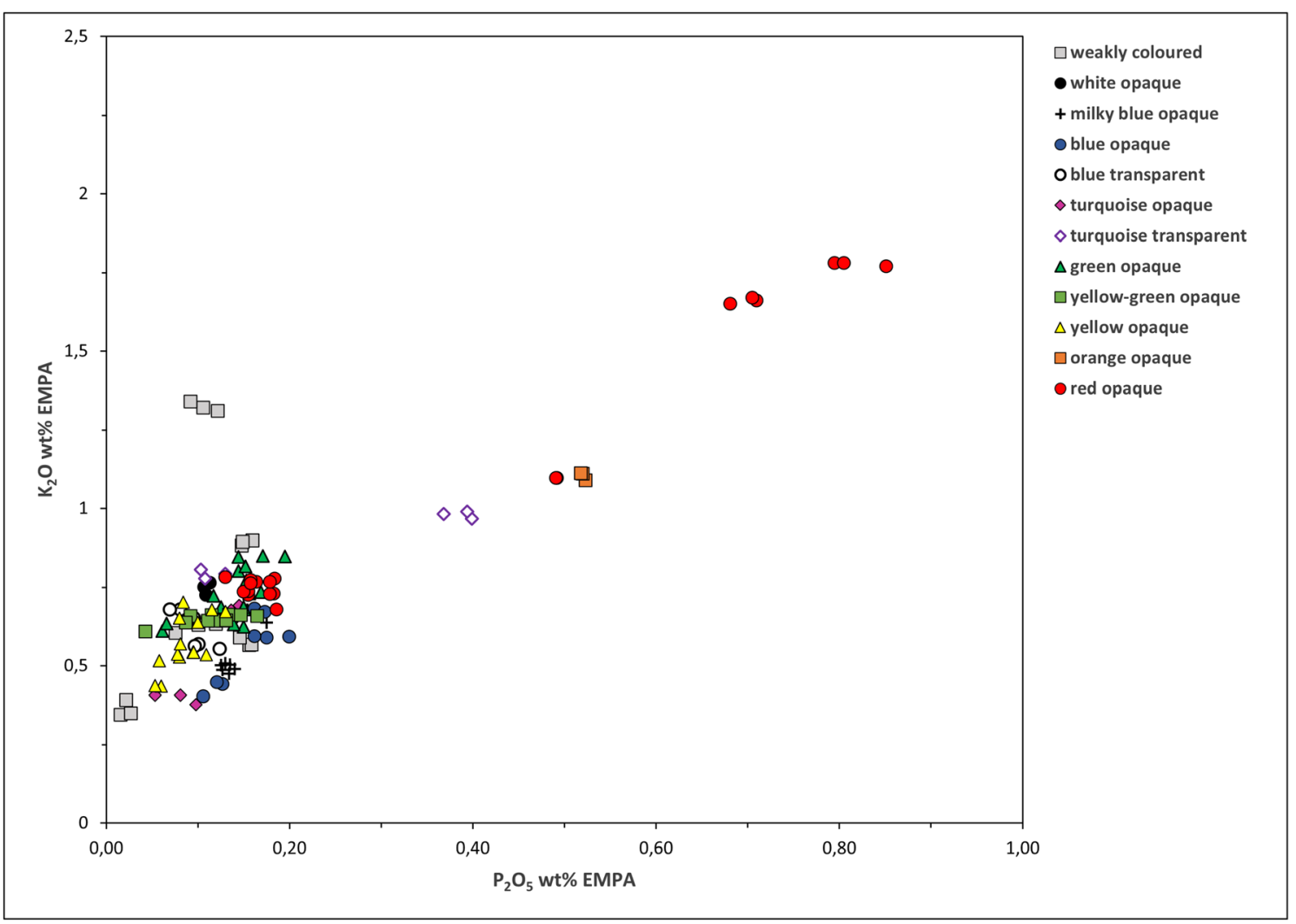

Fig. 5 Potassium oxide versus phosphorus pentoxide concentrations (wt $\%$ ) in Wierum glass. Note that the high-P $+\mathrm{K}$ glasses are all reddish or related colours, related to the colouring process

below the levels that unambiguously point to the use of plant ash (>2.0 wt\%; Lilyquist and Brill 1993), but still leaving a mixture between natron and plant ash as a possibility. However, slightly higher concentrations of $\mathrm{CaO}$ in w20 and w99 compared to the other red glass tessera could indicate that wood ash was added to the glass. It may be possible that some wood or plant ash was incorporated into the batch during the colouration and opacification process (Schibille et al. 2012). Fuel ash frequently still contains fine charcoal fragments which could have served as a reducing agent, favouring the formation of reduced forms of copper and the precipitation of copper metal particles to impart the red hue (Freestone and Stapleton 2015).

\section{The silica source}

The $\mathrm{CaO}, \mathrm{Al}_{2} \mathrm{O}_{3}, \mathrm{TiO}_{2}$, and $\mathrm{Zr}$ contents in ancient glass are some of the relevant indicators that help to differentiate between silica sources (Freestone 2006; Freestone et al. 2018). Calcium and aluminium levels may be influenced by lime, feldspar and clay minerals present in the sand (Freestone 2005). Figure 6 shows the concentrations of calcium $(\mathrm{CaO}$ at $4.9-8.5 \mathrm{wt} \%)$ and aluminium $\left(\mathrm{Al}_{2} \mathrm{O}_{3}\right.$ at $\left.1.4-2.7 \mathrm{wt} \%\right)$. They appear to fall in the range between Roman blue-green and $\mathrm{Sb}$-decoloured compositions and find a strong correlation with first-third century Roman tesserae from Italy and North Africa (Schibille and Freestone 2013).

For most samples, zirconium levels are below $100 \mathrm{ppm}(\mathrm{Zr}$ mean value of $44 \mathrm{ppm}$ ) and titanium levels below $0.2 \mathrm{wt} \%$ $\left(\mathrm{TiO}_{2}\right.$ mean value of $\left.0.1 \mathrm{wt} \%\right)$. These elements are indicative of the amount of silt or the fineness of the sand used. A few samples have high levels for the two elements (w251, w231, w11, w522) and may point to higher concentrations of heavy minerals due to a different origin of the glass or the use of a less pure sand. Levels of $\mathrm{Sr}$ are relatively high (mean value of $425 \mathrm{ppm}$ ) with the exception of a few samples bearing values of below 280 ppm (w113, w70, w13). Sr, being an alkaline earth element, like $\mathrm{Ca}$, is commonly associated with lime, calcium feldspars and clay minerals in sand.

\section{Iron, manganese and HIMT}

In a few samples, manganese oxide concentrations (Fig. 7) are above $0.5 \mathrm{wt} \%$. This may suggest a deliberate addition of $\mathrm{MnO}$ as a decolourizing agent in some of the tesserae (Jackson 2005). Iron $\left(\mathrm{Fe}_{2} \mathrm{O}_{3}\right)$ concentrations show a wide range of concentrations (0.2-3.3 wt\%, see Fig. 7). The high values of iron ( $>1.5 \mathrm{wt} \%)$ are mostly related to red specimens, possibly caused by the deliberate addition of iron slag to achieve reducing conditions within the red opaque glass matrix (Silvestri et al. 2014). 
a

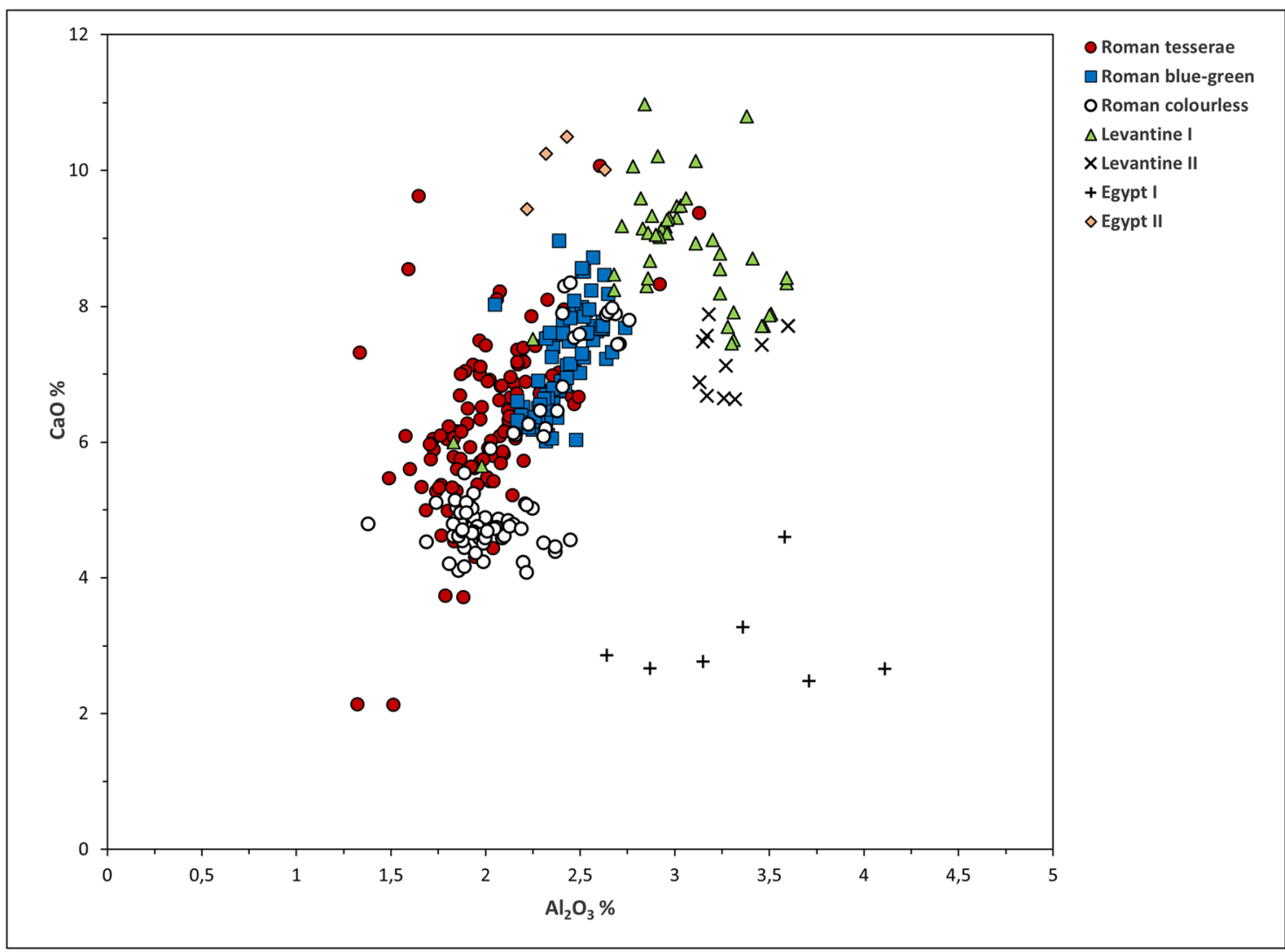

b

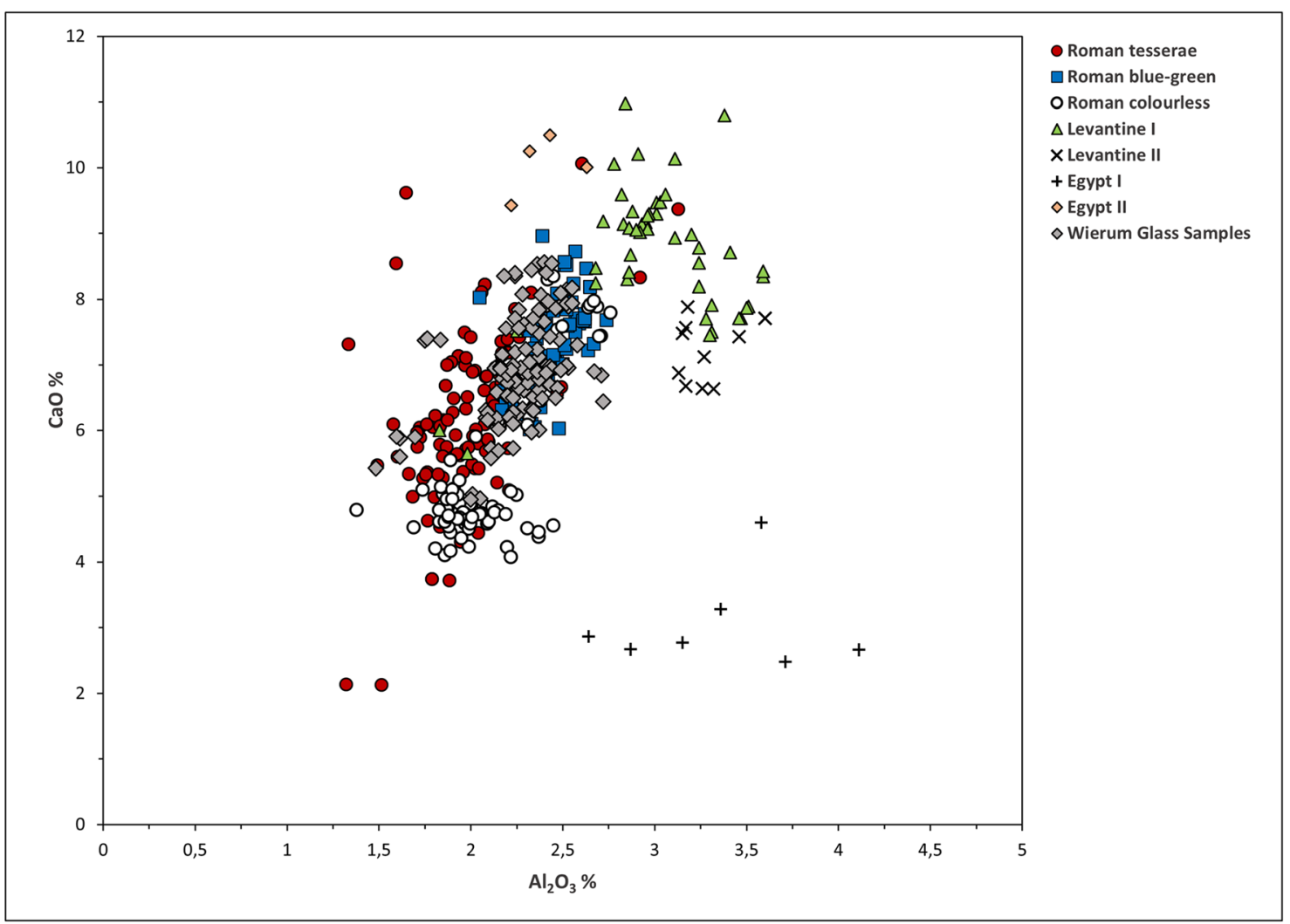


Fig. 6 A Calcium oxide versus aluminium oxide concentrations (wt $\%$ ) of established first millennium production groups (Brems et al. 2018; Freestone et al. 2018; Freestone unpublished data; Schibille and Boschetti 2020; Silvestri et al. 2012). B All Wierum glass samples obtained with EMPA analysis compared with these major glass groups show strong similarities to Roman tesserae and blue-green glass, whereas the Levantine and Egyptian groups are different.

None of the samples match the chemical compositions of proper HIMT glass composition (Freestone 2005; Freestone et al. 2018). However, there are few samples with $\mathrm{TiO}_{2}$ values above $0.2 \mathrm{wt} \%$ that could indicate a different origin for the glass. Looking at these samples in more detail, in w50 the higher levels of iron $\left(\mathrm{Fe}_{2} \mathrm{O}_{3}\right.$ at $\left.1.3 \mathrm{wt} \%\right)$ are probably linked with the red-orange colour since also the manganese percentage is low ( $\mathrm{MnO}$ at $0.2 \%$ ). The other specimens high in titania may point to HIMT variants. Only w231 bears high values for $\mathrm{MnO}(1.3 \mathrm{wt} \%)$ but $\mathrm{Fe}_{2} \mathrm{O}_{3}$ is only at $0.8 \mathrm{wt} \%$. The remaining samples high in titanium and iron do not have relevant amounts of manganese: w5 $\left(\mathrm{Fe}_{2} \mathrm{O}_{3}\right.$ at $1.1 \mathrm{wt} \%$ and $\mathrm{MnO}$ at $0.4 \mathrm{wt} \%)$, w522 $\left(\mathrm{Fe}_{2} \mathrm{O}_{3}\right.$ at $1.1 \mathrm{wt} \%$ and $\mathrm{MnO}$ at $\left.1.0 \mathrm{wt} \%\right)$ and w11 $\left(\mathrm{Fe}_{2} \mathrm{O}_{3}\right.$ at $1.0 \mathrm{wt} \%$ and $\mathrm{MnO}$ at $\left.0.4 \mathrm{wt} \%\right)$.

\section{Colourants and opacifiers}

Three samples in the collection show a white-grey opaque hue and bear high antimony contents $\left(\mathrm{Sb}_{2} \mathrm{O}_{5}\right.$ at 2.2-5.8 $\mathrm{wt} \%$ ). This colour appears to be related to the opacifier, since the only other chromophore present is iron $\left(\mathrm{Fe}_{2} \mathrm{O}_{3}\right.$ at $0.5-1.1$ wt\%), which can only provide, blue, green, yellow and 'black' colours in glass.

For opaque turquoise tesserae, it is unclear how the colour was formed. Various turquoise tesserae have degrees of opacity which appear to be associated with different amounts of copper ( $\mathrm{CuO}$ at $0.8-4.5 \mathrm{wt} \%)$ and antimony $\left(\mathrm{Sb}_{2} \mathrm{O}_{5}\right.$ at $0.6-5.5$ wt\%); cobalt unsurprisingly does not contribute to the colour. We hypothesise that the colour is caused by the presence of calcium antimonate and copper compounds while lead oxide concentrations are negligible varying from being not detected to $0.4 \mathrm{wt} \%$. A fragment of transparent green-blue glass (w30) derives its colour only from the presence of copper oxide $(\mathrm{CuO}=2.0 \mathrm{wt} \%)$. A fragment of transparent turquoise vessel glass (w91) contains $3.1 \mathrm{wt} \%$ cupric oxide. In this specific case, slightly elevated concentrations of $\mathrm{K}_{2} \mathrm{O}$ and $\mathrm{MgO}(>1$ $\mathrm{wt} \%)$ and $\mathrm{P}_{2} \mathrm{O}_{5}(\sim 0.4 \mathrm{wt} \%)$ may indicate a colouring process

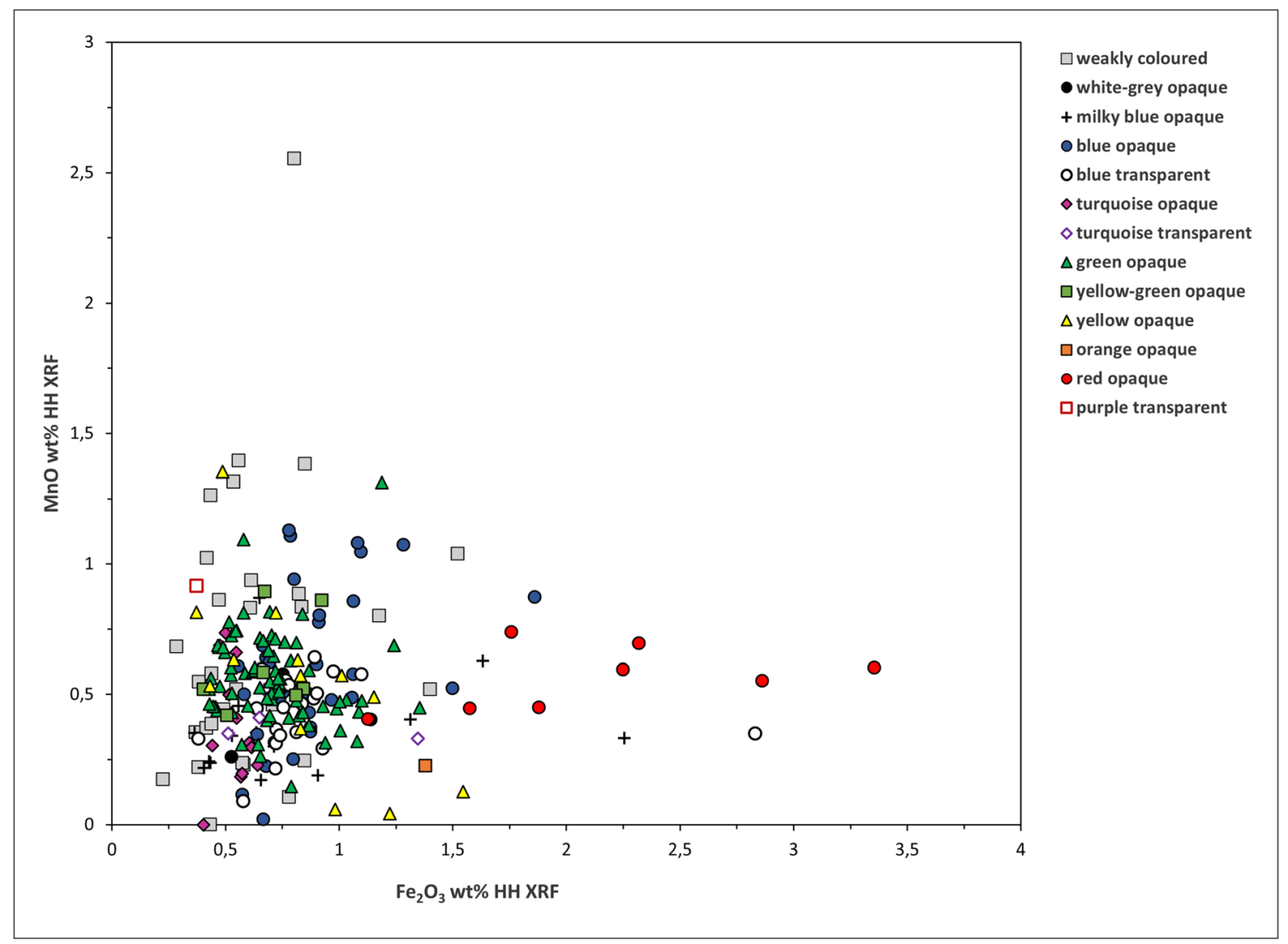

Fig. 7 Iron versus manganese oxide (wt \%) concentrations. Note that concentrations below the detection limit are reported as 0 , and therefore plot on an axis 


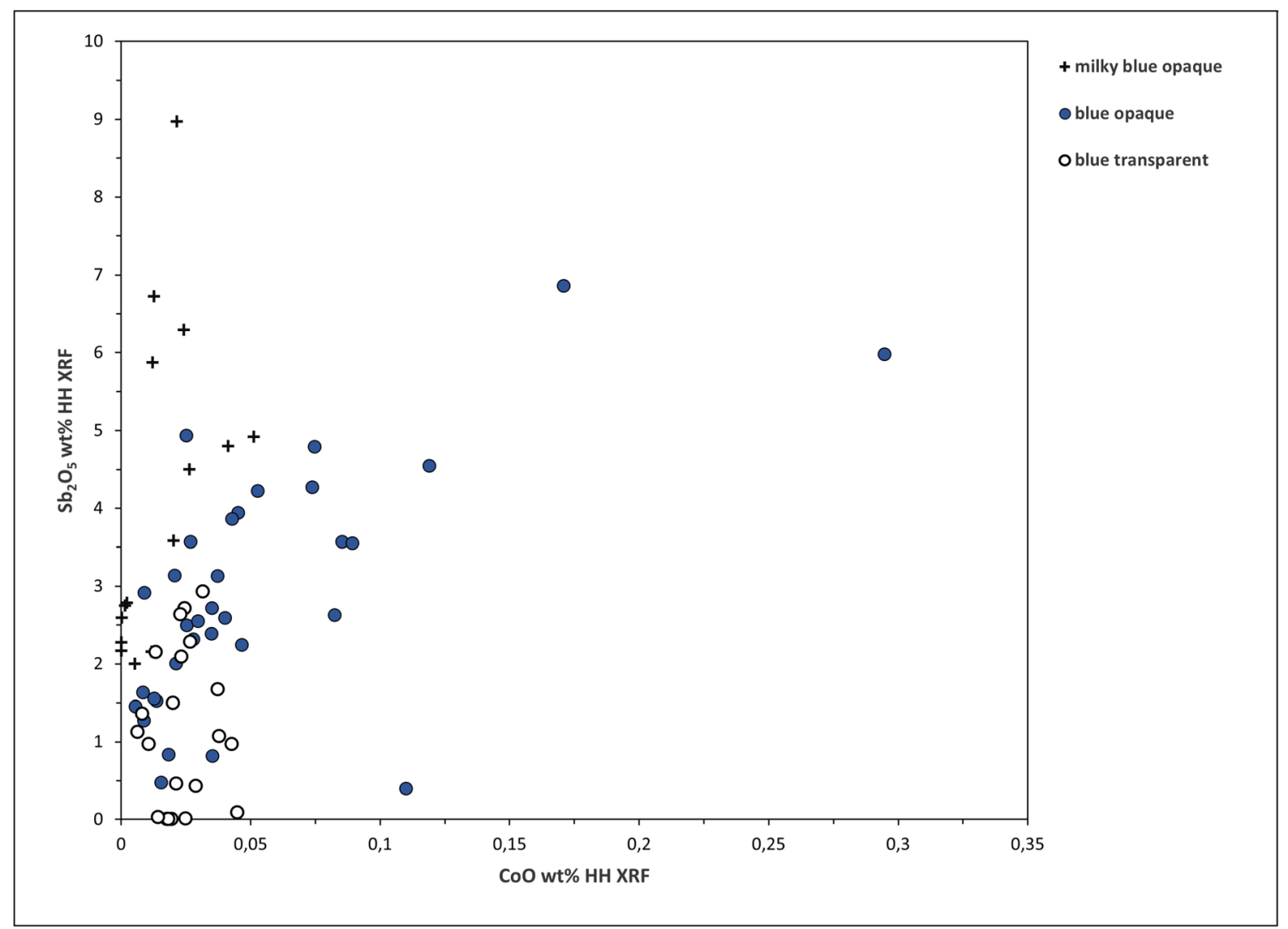

Fig. 8 Relation between blue colours in the Wierum collection and glass composition: Antimony versus cobalt oxide (wt \%) of different types of blue glasses from Wierum. Note that concentrations below the detection limit are reported as 0 , and therefore plot on an axis

akin to that of opaque red glass, though an oxidising furnace atmosphere would have been used. This fragment most likely comes from an early Roman vessel since strong, bright colours were highly fashionable during the first half of the first century.

All the blue glass objects have detectable cobalt concentrations, except for samples w27 and w159. These tesserae probably owe their (more azure) hue only to copper oxide. The specimens' opacity is probably due to calcium antimonate while the presence of cobalt oxide produces a darker hue (Fig. 8). An opaque blue vessel fragment (w31) probably derives its blue hue from the presence of cobalt oxide $(0.02$ $\mathrm{wt} \%$ ), although this is a rather low level, and its opacity from calcium antimonate $\left(\mathrm{Sb}_{2} \mathrm{O}_{5}\right)$ with a mean value of $\left.5.2 \mathrm{wt} \%\right)$.

Opaque milky blue samples were found to be predominantly opacified with antimony $\left(\mathrm{Sb}_{2} \mathrm{O}_{5}\right.$ mean value of 4.1 wt $\%$ ) with added cobalt ( $\mathrm{CoO}$ mean value of $0.01 \mathrm{wt} \%$ ) for the blue colour. Opaque blue glasses were found to have a lower level of antimony $\left(\mathrm{Sb}_{2} \mathrm{O}_{5}\right.$ mean value of $\left.2.8 \mathrm{wt} \%\right)$ and higher amounts of cobalt ( $\mathrm{CoO}$ mean value of $0.05 \mathrm{wt} \%$ ). There are two groups of blue transparent glass which, if present, contain a lower level of antimony $\left(\mathrm{Sb}_{2} \mathrm{O}_{5}\right.$ mean value of $1.1 \mathrm{wt} \%$ ) and cobalt ( $\mathrm{CoO}$ mean value of $0.02 \mathrm{wt} \%$ ).

Both of the opaque yellow and opaque yellow-green objects are coloured and opacified with lead antimonate, except for w113 which is opacified with lead stannate $\left(\mathrm{SnO}_{2}=\right.$ $4.0 \mathrm{wt} \%$ and $\mathrm{PbO}=16.5 \mathrm{wt} \%)$. Yellow opaque tesserae are characterised by higher amounts of lead ( $\mathrm{PbO}$ at 2.4-18.8 $\mathrm{wt} \%)$ and antimony $\left(\mathrm{Sb}_{2} \mathrm{O}_{5}\right.$ at $\left.0.2-2.5 \mathrm{wt} \%\right)$ than yellowgreen samples ( $\mathrm{PbO}$ at 2.0-7.7 wt\%; $\mathrm{Sb}_{2} \mathrm{O}_{5}$ at 0.3-0.7 wt\%). The pale green shade characterising the yellow-green samples is linked with a higher amount of copper within this chromatic group (Arletti et al. 2006; $\mathrm{CuO}$ at $0.4-0.7 \mathrm{wtwt} \%$ ), while it is nearly absent in the yellow glass.

The green objects appear to have been coloured with copper, presumably present in its oxidised form. No cobalt was detected in these objects, even though some of the green-blue samples have a bluish hue. The green colour results from the interaction between the yellow imparted by lead antimonate and the turquoise blue obtained by adding the copper under oxidising conditions. Average levels of copper are similar in the bright green $(\mathrm{CuO}=2.3 \mathrm{wt} \%)$ and dark green $(\mathrm{CuO}=1.8$

Fig. 9 The relationship between green colours in the Wierum collection and glass composition illustrate how the ratios between copper, lead and antimony determine the colour spectrum for different shades of green: $\mathbf{A}$ lead versus copper oxide (wt \%) concentrations. B Ternary plot of lead, antimony and copper oxide (wt $\%$ ) concentrations of the analysed green Wierum glasses. Note that 'concentrations' below the detection limit are reported as 0 , and therefore plot on the axis 

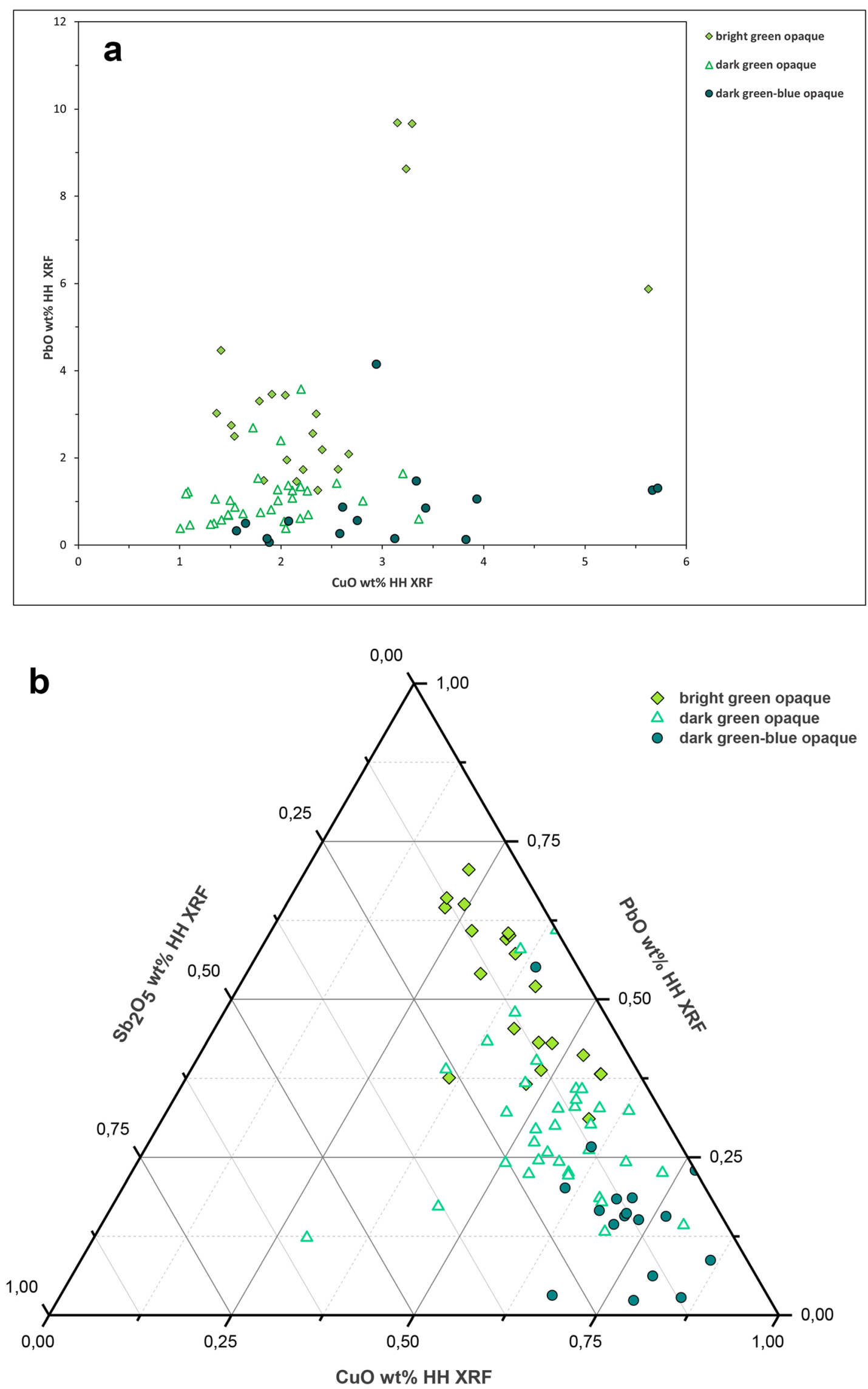
wt\%) groups while the dark green-blue/turquoise group is marked by a higher value $(\mathrm{CuO}=3.2 \mathrm{wt} \%)$ which may be responsible for the darker bluish colour. Lead appears to be a discriminant in the colour differentiation of the tesserae, imparting different shades of yellow to the glass. Figure 9A, $\mathrm{B}$ illustrates the how the ratios between copper, lead and antimony determine the colour spectrum between different shades of green. A greyish "pea" green glass fragment (w32) contains noticeable levels of lead antimonate $\left(\mathrm{Sb}_{2} \mathrm{O}_{5}=\right.$ $4.1 \mathrm{wt} \%$ and $\mathrm{PbO}=5.8 \mathrm{wt} \%$ ) and a consistent copper oxide content $(\mathrm{CuO}=5.6 \mathrm{wt} \%)$. This fragment is most likely to be from an early Roman moulded bowl or dish.

Opaque red glass in general has a heterogeneous glass matrix and distribution of the red colour within it. Also, bubbles are frequent and dark stripes are present in most of the objects. Based on their appearance and composition, the Wierum red glass probably falls into the category of dull red glass because of its pale colour and low copper-low lead composition (Boschetti et al. 2016a; Freestone 1987; Henderson 1991; van der Werf et al. 2009). The already mentioned high values for $\mathrm{MgO}$ and $\mathrm{K}_{2} \mathrm{O}$ for two red samples are consistent with other published values for this glass colour (Boschetti et al. 2016a). Levels of copper are generally low ( $\mathrm{CuO}$ at 0.9-3.9 wt\%), while the lead content is present at variable levels ( $\mathrm{PbO}$ at $0.5-9.3 \mathrm{wt} \%)$. The high level of iron $\left(\mathrm{Fe}_{2} \mathrm{O}_{3}\right.$ at 1.1-3.3 wt\%) in the red opaque tesserae is particularly evident as compared to other chromatic groups in our collection. High contents of iron (and lead) indicate that these elements were added intentionally to the glass matrix, probably to create a highly reducing atmosphere that moves the copper redox equilibrium towards $\mathrm{Cu}(0)$. This promotes the precipitation of metallic copper globules as well as increasing the size of these globules (Brill and Cahill 1988; Freestone et al. 2003; Schibille et al. 2012; van der Werf et al. 2009).

The only orange opaque sample (w50) contains a darker red-orange stripe. Due to its semi-melted state, it is unclear whether this is a heterogeneous orange tessera, or refuse from working two glass colours, but orange and red-banded tesserae are mentioned in Boschetti et al. (2016a), Barca et al. (2016), Maltoni and Silvestri (2018) and Schibille and Boschetti (2020). The compositions of the two colours are similar and marked by high amounts of lead ( $\mathrm{PbO}$ mean value $15.4 \mathrm{wt} \%)$, copper ( $\mathrm{CuO}$ mean value $9.2 \mathrm{wt} \%)$ and iron $\left(\mathrm{Fe}_{2} \mathrm{O}_{3}\right.$ mean value $\left.1.6 \mathrm{wt} \%\right)$. The main difference between the red and the orange samples is the higher level of antimony in the latter $\left(\mathrm{Sb}_{2} \mathrm{O}_{5}\right.$ mean value $\left.1.2 \mathrm{wt} \%\right)$, presumably yellow lead-antimonate. Maltoni and Silvestri (2018) and Schibille and Boschetti (2020) indicate, however, that the colour differences in their tesserae are related to varying copper concentrations, so it remains unclear whether these are actually the same types of tesserae as the Wierum specimen.

A melted fragment of transparent amethyst purple glass (w33) derives its colour from the use of manganese oxide as a chromophore $(\mathrm{MnO}=0.9 \mathrm{wt} \%)$. Specimen w33 contains the highest value of strontium $(\mathrm{Sr}=613 \mathrm{ppm})$ compared to other glasses. This may be interpreted as indicating a different silica or lime source for this fragment, but it is more likely that a Srrich manganese source was used as pigment/chromophore (see, e.g. Huisman et al. 2017 for the relation between $\mathrm{Sr}$ and manganese). The colour is typical of early Roman glass production of the first half of the first century AD.

The almost exclusive adoption of antimony for the formation of both opacity and colour is typical of a first-third century AD Roman tradition (Mass et al. 1998; Tite et al. 2008; Verità et al. 2013). A relatively consistent presence of tin in the turquoise $\left(\mathrm{SnO}_{2} 0.0-0.3 \mathrm{wt} \%\right)$, green $\left(\mathrm{SnO}_{2} 0.0-0.6 \mathrm{wt} \%\right)$, red $\left(\mathrm{SnO}_{2} 0.1-0.6 \mathrm{wt} \%\right)$ and orange glass $\left(\mathrm{SnO}_{2}\right.$ mean value $0.3 \mathrm{wt} \%$ ) could be associated with the use of tin-bronze scrap introduced in the batch as a source of copper (Brill and Cahill 1988; Shortland and Tite 2000; van der Werf et al. 2009).

\section{Colourless and weakly coloured glass}

A variety of glass objects in the collection are not tesserae or vessel fragments. Most are of weakly coloured transparent glass drops. These objects were probably remelted as part of glass working, indicating they could originate from a glass workshop. These samples are characterised by the highest transparency, as compared with other glass objects in the collection. The occasional greenish hue can be attributed to the presence of iron oxides $\left(\mathrm{Fe}_{2} \mathrm{O}_{3}\right.$ at $\left.0.2-1.5 \mathrm{wt} \%\right)$, probably a contaminant in the silica source.

Several of these objects (w88, w236, w237, w249) show banding or black streaks. EPMA results indicate that the black line of object w237 (a drop of greenish transparent glass), seems to be caused by very high levels of iron $\left(\mathrm{Fe}_{2} \mathrm{O}_{3}\right.$ mean value $\left.20.2 \mathrm{wt} \%\right)$ while in sample w243, the brownish stripe shows elevated lead contents ( $\mathrm{PbO}$ mean value $2.35 \mathrm{wt} \%$ ). These fragments may be biproducts from glass working, possibly iron oxide scale introduced from beadmaking tools. The colourless, aqua and naturally coloured glass do not contain enhanced values of colourant elements like lead and copper, so we can exclude the reuse of coloured glass tesserae (Mirti et al. 2000, 2001; Schibille and Freestone 2013; Freestone 2015). The presence of the colourless, aqua and naturally coloured glass in the collection must be due to the recycling of Roman glass, as these types of glass were widely used in Roman windowglass, glass vessels and tableware. A recent study reveals that in Byzantine Jordan from the sixth century onwards there was also a shortage in raw glass procurement and that colourless glass was systematically collected and reused (Boschetti et al. 2021). Recycling of blue-green Roman glass is also seen in the West, for instance at San Vincenzo where blue-green window glass, presumably taken from a nearby Roman building, 


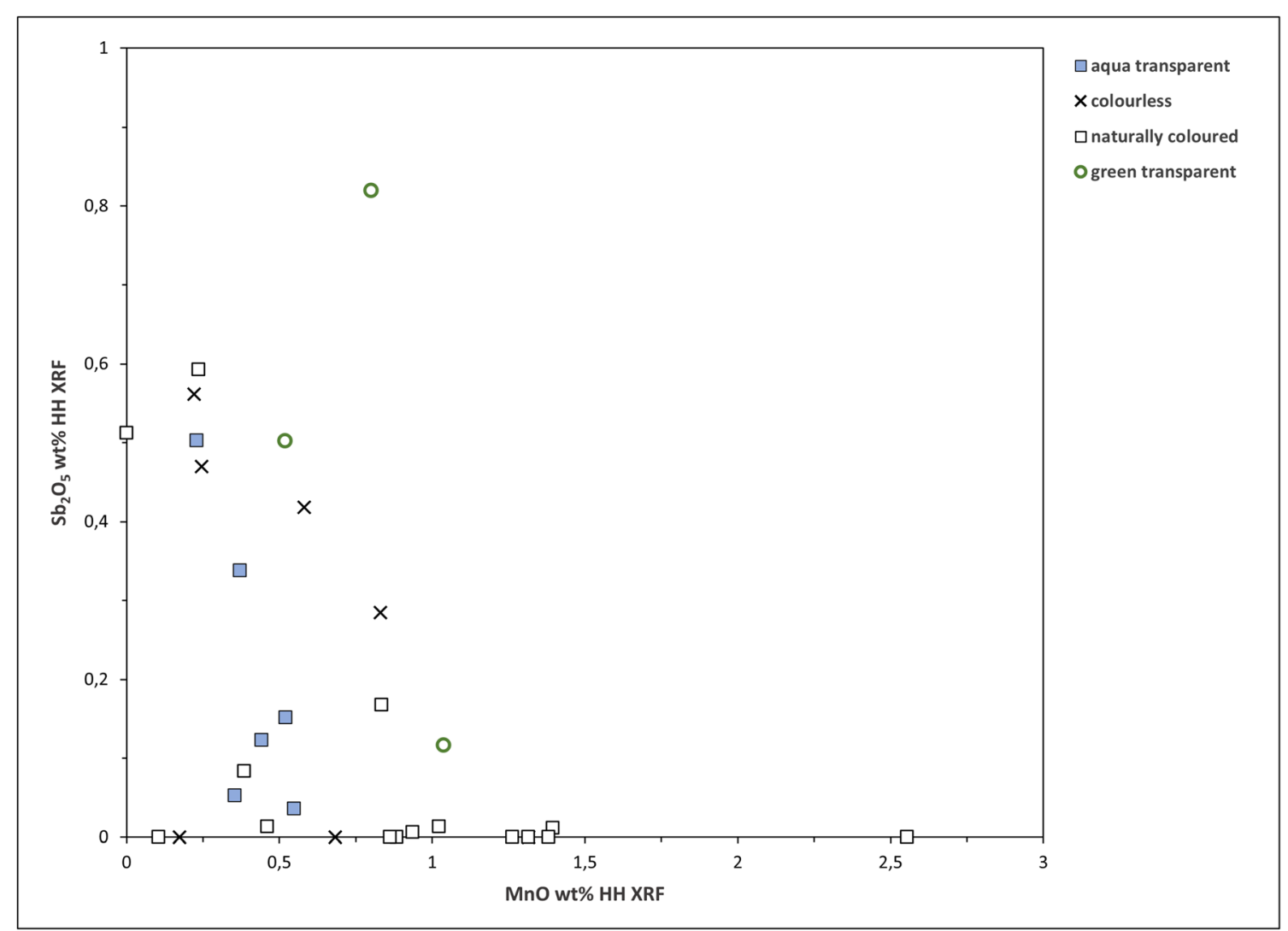

Fig. 10 Use of decolourisers in the Wierum colourless and naturally coloured glasses: antimony versus manganese oxide (wt\%) concentrations. Note that concentrations below the detection limit are reported as 0 , and therefore plot on an axis

was recycled in the ninth century for the production of vessel and window glass in the monastery (Schibille and Freestone 2013).

Figure 10 shows that some of the objects have been decolourised with the deliberate addition of antimony $\left(\mathrm{Sb}_{2} \mathrm{O}_{5}>0.2 \mathrm{wt} \%\right.$; Sayre and Smith 1967) but also contain a background concentration of manganese $(\mathrm{MnO}<0.5 \mathrm{wt} \%)$. A second group of glass is determined exclusively by the addition of manganese $(\mathrm{MnO}>0.5 \mathrm{wt} \%)$ and by the absence of antimony. A third, more heterogeneous group is formed by both the elements at a significant level in the compound. This kind of mixed $\mathrm{Mn}+\mathrm{Sb}$ glasses has been interpreted as being evidence for recycling (Freestone 2015; Jackson 2005; Maltoni et al. 2016). As pointed out by Maltoni et al. (2016), even if not deliberate, the addition of both the decolourisers is possibly related to the selective choice of this glass for recycling, with the final aim of obtaining a colourless glass. It is not infrequent in large Roman assemblages (Foster and Jackson 2010; Jackson 2005; Jackson and Paynter 2016).

\section{Origin of the tesserae}

Although the tesserae could in theory have been imported as fresh raw materials, resulting from Byzantine and Islamic mosaic production, the analyses make clear that these are Roman tesserae of the first-third centuries. Moreover, remnants of cement or plaster attached to some of the tesserae indicate that they were removed from mosaics. This origin is corroborated by the presence in the collection of various stone tesserae, a fragment of Egyptian blue and possibly glass vessel fragments.

During an initial phase of Roman wall and vault mosaics (end of the second century BC to early first century AD), possibly inspired by the sacred grotto of the nymphs, mosaicists employed diverse materials to produce irregular surfaces recalling natural caves (Lavagne 1988). The wall mosaics were created by mixing pumice, seashells, Egyptian blue, and a few glass elements, like twisted rods, revetment plaques, and moulding strips or recycled vessel glass shards. During this early phase, proper glass tesserae are absent in wall mosaics: the application of coloured glass tesserae appears only during the first half first century $\mathrm{AD}$, after glass blowing spread across the Mediterranean (Boschetti 2011; Boschetti et al. 2012). Stone and shells disappeared from wall mosaics after the first century, but Egyptian blue remained in use into the second century (Sear 1977). Glass mosaics remain in the Mediterranean for centuries (Sear 1977; Boschetti 2011).

There is clear macroscopic evidence that the tesserae had been prepared for recycling: some tesserae have been broken up, as is evidenced by sharp edges and conchoidal fractures. 
This was probably done to facilitate melting in a cruciblealthough the colourless and weakly coloured ones may have been broken previously to remove gold foil if they had been part of gold foil tesserae. Many tesserae have been heat-treated, potentially in preparation for making glass beads.

An interesting aspect which needs to be considered is the age of the mosaic(s) that was (were) reused as source material for medieval glass bead production at Wierum. The concentrations of calcium and aluminium are in the range for mosaic tesserae of first to third century AD Roman tradition from Italy and North Africa (Schibille and Freestone 2013). Moreover, the almost exclusive use of antimony-based opacification for all the opaque tesserae is typical of an early Roman tradition until the fourth century AD (Mass et al. 1998; Tite et al. 2008). Therefore, the stone tesserae and the Egyptian blue pebble could have been collected accidentally with glass tesserae during the frequent spoliation of lavishly decorated Roman buildings (Cavalieri and Giumlia-Mair 2009; Freestone 2015; Munro 2020). Two fragments of early ninth century crucibles from a Benedictine monastery at San Vincenzo al Volturno (Italy) - containing non-melted white marble tesserae in a translucent base glass - show how easy it was to mistake stone tesserae for glass ones (Schibille and Freestone 2013).

The combination of volcanic stones, Egyptian blue and coloured vessel fragments may even indicate that the collection originates from one or more buildings that contained a combination of first century AD shell mosaics, early glass mosaics and glass tesserae mosaics or transitional forms as described by Sear (1977).

\section{Implications of the glass collection}

From the scientific investigations of the glass finds, it is possible to state that glassworking on the wierde was almost exclusively based on the recycling of Roman glass. Highly coloured Roman glass is present in the form of tesserae and early Roman vessel glass. Analyses of weakly coloured transparent drops also point to the Roman origin of this glass.

A small lump of opaque lead-tin opacified yellow glass (Fig. 3.17) may be Roman in date, but can also represent the only Early Medieval glass in the collection. In the Netherlands, lead-tin yellow glass was worked on three Merovingian beadmaking sites (see $\S 1.4$ ) as well as in a Carolingian beadmaking context in the agrarian settlement of Dorestad-Veilingterrein (Sablerolles and Henderson 2012). Lead-stannate yellow glass was traded in the shape of discs or 'cakes' for the production of beads in Ribe (Andersen and Sode 2010).

Although it is common to find scrap vessel glass among Early Medieval glass bead production waste from the Netherlands and Scandinavia, this is usually from an earlier medieval phase (Sablerolles et al. 1997; Andersen and Sode
2010). If Roman glass is present, this is usually in the form of thick-walled blue-green glass which mostly postdates the highly coloured Wierum vessel fragments. Blue-green glass would have been widely available in the former Roman northern provinces (from ruins and graves), whereas early-Roman highly coloured glass is far more likely to come from further south, supporting our suggestion that the Wierum glass collection derived from one or more early Roman prestigious building in the Mediterranean (see $\S 3.4$ ).

The presence of complete, fragmented and heat-affected tesserae, scrap vessel glass and glassworking refuse suggests that glass beads were made on or near the terp, most likely in the Carolingian period. The presence of amber fragments in the collection could indicate glass beads and amber beads, or other decorative items, were made in the same workshop. The co-occurrence of glass and amber beadmaking has been observed on other Dutch and Scandinavian beadmaking sites (Henderson et al. 2019).

Evidence for the practice of crushing tesserae was found at Dorestad-Veilingterrein (Sablerolles and Henderson 2012), Ribe (Andersen and Sode 2010) and Åhus (Callmer \& Henderson 1991), where it was suggested this was done to facilitate melting in a crucible. A crucible with a thin layer of almost colourless glass was found in a beadmaking context at Dorestad (PPAH-excavations). Stuck in the transparent base glass is a small amount of opaque white melted glass, probably a fragmentary opaque white tessera; small defects in the glass are believed to indicate the locations of fragmentary tesserae that are now lost (Preiß 2010). In this case, the reason for adding coloured tesserae to the base glass was to increase its volume, not to colour it, as colours such as opaque red, yellow, and white would be lost when the glass was remelted (Freestone 2015). It is therefore possible that the weakly coloured transparent drops in the Wierum collection represent glass that was worked in crucibles, especially when the high iron and lead levels in some of the drops are considered suggestive of contamination from beadmaking tools (see $\S 3.4$ ). A small amount of melted, naturally coloured glass (w250) in the collection appears to have the remains of a crucible adhering, but this requires further investigation. It is also possible that some of the weakly coloured glasses in the Wierum collection may, however, represent melted tesserae which had their gold foil removed previously.

Many tesserae are affected by heat, potentially in preparation for making glass beads by pre-heating them in an iron pan and working them directly into beads (see "Recycling and reuse"). Tesserae could also have melted accidentally given the high-temperature environment of the workshop. If tesserae and scrap vessel glass were indeed directly worked into beads, this can help explain why one characteristic category of glass bead production waste, glass rods, is conspicuously absent from the collection. To this day, glass rods are used especially for making glass beads. Glass rods are well represented on 
most Early Medieval beadmaking sites, e.g. in the Netherlands at Merovingian Maastricht and Rijnsburg (Sablerolles et al. 1997; Dijkstra et al. 2010) and in Scandinavia at Ribe (Andersen and Sode 2010) and Åhus (Callmer \& Henderson 1991). However, Carolingian Dorestad yielded very few glass rods (Preiß 2010) implying the same technique suggested here for Wierum could have been used by beadmakers at Dorestad.

Whether the colour ratio of tesserae assemblages found on northern beadmaking sites is representative of the bead colours preferred by Early Medieval beadmakers is arguable (Preiß 2010; Henderson et al. 2019). The colour spectrum of the Wierum tesserae is heavily dominated by greens and blues, something which is also reported for several, though not all, eighth to ninth century northern beadmaking sites (Henderson et al. 2019). This may simply reflect the colour ratios found in Roman wall and vault tesserae which are similarly dominated by blues and greens (Sear 1977). In combination with the non-glass materials in the Wierum collection, this makes it likely that these tesserae were imported in bulk, rather than as pre-ordered batches of colours. At the same time, this colour spectrum may hint at the types of beads produced on the terp such as small, wound cylindrical beads in various opaque colours, which were popular in Scandinavia, the Baltic and the northern Carolingian empire during the second half of the eighth and early ninth century (Callmer 1997; Sablerolles 1999; Pöche 2005; Theune 2008; Sablerolles and Henderson 2012), pointing at contacts between beadmakers on the northern edge of the Frankish empire and Scandinavia. Green, blue-green and red were especially popular colours. Equally popular were small cylinders of 'black', opaque red and naturally coloured greenish glass decorated with yellow trails, including black 'wasp beads'. The bright green opaque colour of a plano-convex drop (w34) in the Wierum assemblage corresponds with that of 19 similarly coloured tesserae (Table 2). It has a small indent, possibly a mark of a beadmaking tool (Fig. 3.21). Small cylindrical beads of this colour were also found in Carolingian contexts in Dorestad (Veilingterrein-excavations) where they were possibly made (Sablerolles and Henderson 2012). In this respect, the location of the wierde at Wierum is interesting as it would have been easily accessible for beadmakers travelling from Dorestad along the Wadden Sea coast and the river Hunze.

\section{The socio-political implications}

The eighth or perhaps ninth century, the period in which the tesserae assemblage is thought to have arrived in Wierum, falls in the period during which the region was incorporated into the Frankish empire. As this settlement may have been the home of a local leader in the Merovingian period, it may still have had regional political significance in the Carolingian period, especially since its position on the wide river Hunze, which connected the Wadden Sea and North Sea with the interior. The political status and convenient location may have attracted itinerant craftsmen such as beadmakers.

The presence of workshops with a more permanent character, including one for the production of beads from glass and other materials, is certainly a possibility. This may have been combined with other high temperature crafts such as metal working. The chance of ever finding evidence of a permanent artisanal area, however, is very small, as only a very small portion of the terp has been left intact. Still, the assemblage and its characteristics testify that Wierum was a high-status site with skilled artisanal production and far-reaching connections.

\section{Conclusions}

The Wierum glass collection is unique in the Netherlands and contains its largest tesserae find to date. Although the collection is without detailed context, its significance lies not only in the large number, but also in the combination of the finds made from different materials, which points to the presence of a glass and probably amber bead-making workshop on the terp in the Early Medieval period.

The presence of fragmented and partially molten tesserae, some early Roman highly coloured vessel glass, and glass working refuse in the Wierum tesserae collection, combined with the presence of melted lumps and amber fragments indicate that the tesserae were probably meant to be used for the production of small, wound monochrome and simply trailed beads in a glass beadmaking workshop. The same combination of glass and amber also occurs in other Dutch and Scandinavian bead production sites.

The analyses show that the tesserae are of Roman rather than Byzantine origin, and probably of first century AD date. Since some still have cement attached to them, the tesserae must be spolia from one or more glass mosaics in first to third century high-status Roman buildings that were transported northwards to serve as raw materials for glass bead production. The colour range and a suite of accompanying non-glass materials closely match that of first century AD Roman mosaics, which suggests that spoliation and transport and trade occurred in bulk, without pre-selection of. colours.

The Wierum glass workshop may have been temporary, set up by a travelling beadmaker carrying his own supply of raw materials. However, since Wierum is thought to have been the home of a regional leader in the Merovingian period, and strategically located, the site may have had regional political significance in the Carolingian period. The presence of workshops with a permanent character, including one for the production of beads, possibly in combination with amber working or another high-temperature craft such as metal working, 
is therefore plausible. Therefore, despite the lack of direct context information, there is enough evidence in the nature and composition of the assemblage to indicate a supraregional importance in trade and craft of the Wierum terp.

Supplementary Information The online version contains supplementary material available at https://doi.org/10.1007/s12520-021-01391-4.

Acknowledgements We wish to thank Jelle Schokker of the Northern Archaeological Depot in Nuis for all his help with making this assemblage accessible for study this assemblage, and for the permission sample the objects for EPMA analysis. We wish to thank Ian Freestone of University College, London for providing us with his datasets with compositional analyses on Roman tesserae.

Authors' contributions

$\mathrm{HH}, \mathrm{RC}$ and $\mathrm{AN}$ initiated the project. RC performed the XRF analyses under BvO's supervision. JH and YS sampled and arranged for the EPMA analyses. RS made the graphs and led the writing of the manuscript, with contributions by all.

Data availability All relevant data is made available in supplementary data files.

\section{Declarations}

Conflicts of interest/Competing interests The authors declare no conflict of interest, nor competing interests.

Open Access This article is licensed under a Creative Commons Attribution 4.0 International License, which permits use, sharing, adaptation, distribution and reproduction in any medium or format, as long as you give appropriate credit to the original author(s) and the source, provide a link to the Creative Commons licence, and indicate if changes were made. The images or other third party material in this article are included in the article's Creative Commons licence, unless indicated otherwise in a credit line to the material. If material is not included in the article's Creative Commons licence and your intended use is not permitted by statutory regulation or exceeds the permitted use, you will need to obtain permission directly from the copyright holder. To view a copy of this licence, visit http://creativecommons.org/licenses/by/4.0/.

\section{References}

Andersen JH, Sode T (2010) The glass bead material. In: Bencard M, Brinch Madsen H (eds), Ribe excavations 1970-76, vol. 6, Hojbjerg, $17-59$

Arletti R, Quartieri S, Vezzalini G (2006) Glass mosaic tesserae from Pompeii: an archeometrical investigation. Periodico Mineralogia 76:25-38

Barca D, Basso E, Bersani D, Galli G, Invernizzi C, Francesco La Russa M, Paolo Lottici P, Malagodi M, Antonio Ruffolo S (2016) Vitreous tesserae from the calidarium mosaics of the Villa dei Quintili, Rome. Chemical composition and production technology, Microchemical Journal 124:726-735

Boschetti C (2011) Vitreous materials in early mosaics in Italy: Faience. Egyptian blue and glass, Journal of Glass studies 53:59-91

Boschetti C, Leonelli C (2016) Glass colouring and recycling in Late Antiquity: a new case study from Aquileia (Italy). Journal of Glass Studies 58:69-86
Boschetti C, Leonelli C, Corradi A (2012) The earliest wall mosaics and the origin of Roman glass in Italy: archaeological considerations for an archaeometric study. Proceedings of the AIHV 18th Congress, 139-144

Boschetti C, Mantovani V, Leonelli C (2016) Glass coloring and recycling in late antiquity: a new case study from Aquileia (Italy). Journal of Glass Studies 58:69-86

Boschetti C, Henderson J, Evans J, Leonelli C (2016a) Mosaic tesserae from Italy and the production of Mediterranean coloured glass (4rd century BCE-4th century CE) Part I: Chemical composition and technology. J Archaeol Sci Rep 7:303-311

Boschetti C, Lichtenberger A, Raja R, Wootton W, Schibille N (2021) Loose glass tesserae and lost decorations: chronology and production of mosaics from Gerasa's Northwest Quarter. Archaeometry. https://doi.org/10.1111/arcm.12654

Brems D, Degryse P, Hasendoncks F, Gimeno D, Silvestri A, Vassilieva E, Luypaers S, Honings J (2012) Western Mediterranean sand deposits as raw material for Roman glass production. J Archaeol Sci 39:2897-2907

Brems D, Freestone I, Gorin-Rosen Y, Scott R, Devulder V, Vanhaecke F, Degryse P (2018) Characterisation of Byzantine and early Islamic primary tank furnace glass. J Archaeol Sci Rep 20:722-735

Brill RH (1999) Chemical analyses of early glasses, volume 2, tables of analyses. The Corning Museum of Glass, Corning, NY

Brill RH, Cahill N (1988) A red opaque glass from Sardis and some thoughts on red opaques in general. Journal of Glass Studies 30: $16-27$

Callmer J (1997) Beads and bead production in Scandinavia and the Baltic Region c AD 600-1100: a general outline. In: von Freeden U, Wieczorek A (eds), 1997 Perlen Archäologie, Techniken, Analysen, Akten des Internationalen Perlensymposiums in Mannheim vom 11 Bis 14 November 1994, Bonn (Kolloquien zur Vor- und Frühgeschichte, Band 1), 197-202

Cavalieri M, Giumlia-Mair A (2009) Lombardic glassworking in Tuscany. Mater Manuf Process 24:1023-1032

Dijkstra MFP, Sablerolles Y, Henderson J (2010) A traveller's tale. Merovingian glass bead production at Rijnsburg, the Netherlands. In: Theune C, Biermann F, Struwe R, Jeute GH (eds), Zwischen Fjorden und Steppe. Festschrift für Johan Callmer zum 65 Geburtstag, Rahden (Internationale Archäologie Studia honoraria 31), $175-200$

Dunbabin K (1999) Mosaics of the Greek and Roman world New York: Cambridge University Press

Fijma, P (2008) Archeologisch onderzoek Wierde Wierum. Inventariserend Veldonderzoek d.m.v. proefsleuven (= Grontmij Archeologische Rapporten 365). Grontmij, Assen.

Foster H, Jackson C (2010) The composition of late Romano-British colourless vessel glass: glass production and consumption. J Archaeol Sci 37:3068-3080

Freestone I (1987) Composition and microstructure of early opaque red glass. In: Bimson M, Freestone I (eds) Early Vitreous Materials (British Museum Occasional Paper 56), Brittish Museum, 173-191

Freestone I (2005) The provenance of ancient glass through compositional analysis. Materials Research Society Symposium Proceedings Vol. 852 OO81.1 - 14

Freestone I (2006) Glass production in Late Antiquity and the Early Islamic Period: a geochemical perspective. In: Maggetti M, Messiga B (eds), Geomaterials in Cultural Heritage, Geological Society, London (Special Publications 257) $201-216$

Freestone I (2008) Pliny on Roman glassmaking. Archaeology, History and Science, pp 77-100

Freestone I (2015) The recycling and reuse of Roman glass: analytical approaches. Journal of glass studies 57:29-40

Freestone IC, Stapleton C (2015) Composition technology and production of coloured glasses from Roman mosaic vessels. In: Bayley J, 
Freestone IC, Jackson C (eds) Glass of the Roman world. Oxbow, Oxford, UK, pp 61-76

Freestone IC, Gorin-Rosen Y, Hughes MJ (2000) Primary glass from Israel and the production of glass in late antiquity and the early Islamic period. In: Nenna M-D (ed) La Route Du Verre: Ateliers Primaires Et Secondaires Du Second Millénaire Av J-C Au Moyen Age. Lyon, Maison de l'Orient Méditerraneéan-Jean Pouilloux, pp $65-84$

Freestone I, Stapleton C, Rigby V (2003) The production of red glass and enamel in the Later Iron Age, Roman and Byzantine periods. Entwistle C, Through a glass brightly - studies in Byzantine and Medieval Art and Archaeology. Presented to David Buckton, Oxbow Books, Oxford, In, pp 142-154

Freestone I, Degryse P, Lankton J, Gratuze B, Schneider J (2018) HIMT, glass composition and commodity branding in the primary glass industry. In: Rosenow D, Phelps M, Meek A, Freestone I (eds) Things that travelled: Mediterranean glass in the first millennium AD. UCL Press, London, pp 159-190

Glasbergen W (1944) Terra sigillata uit de provincie Groningen, bijdrage tot de geschiedenis van den handel in den Romeinschen tijd. Jaarverslagen van de Vereniging voor Terpenonderzoek 25-28: $317-368$

Heaser S (2018) Anglo-Saxon Glass Beadmakers, s.l. 19 pp https:// wwwresearchgatenet/publication/339178110_ANGLO-SAXON_ GLASS BEADMAKERS Accessed $21 \mathrm{Feb} 2021$

Henderson J (1985) The raw materials of early glass production. Oxf J Archaeol 4(3):267-291

Henderson J (1988) Electron probe microanalysis of mixed-alkali glass. Archaeometry 30:77-91

Henderson J (1991) Technological characteristics of Roman enamels. Jewellery Studies 5:64-76

Henderson J (2013) Ancient glass, an interdisciplinary exploration. Cambridge University Press, New York and Cambridge

Henderson J, Chenery S, Faber E, Kröger J (2016) The use of Electron probe microanalysis and laser ablation-inductively coupled plasmamass spectrometry for the investigation of 8th-14th century plant ash glasses from the Middle East. Microchem J 128:134-152

Henderson J, Sode T, Sablerolles Y (2019) Early medieval tesserae from Scandinavia and the Netherlands: a case for recycling. In: Van Wersch L, Verslype L, Strivay D, Theuws F (Eds) Early Medieval tesserae in Northwestern Europe. (Merovingian Archaeology in the Low Countries 6). Habelt-Verlag, Bonn, pp 68-95

Huisman DJ, van der Laan J, Davies GR, van Os BJH, Roymans N, Fermin B, Karwowski M (2017) Purple haze: combined geochemical and $\mathrm{Pb}-\mathrm{Sr}$ isotope constraints on colourants in Celtic glass. J Archaeol Sci 81:59-78

Jackson C (2005) Making colourless glass in the Roman Period. Archaeometry 47:763-780

Jackson CM, Paynter S (2016) A great big melting pot: Exploring patterns of glass supply, consumption and recycling in Roman Coppergate, York. Archaeometry 58:68-95

James L (2017) Mosaics in the medieval world: from late antiquity to the fifteenth century Cambridge University Press. York, New

Knol E (1996) Een Beerput met apostelkoppen in Groningen. Stad \& Lande 5(3):2-7

Lahlil S, Biron I, Cotte M, Susini J (2010) New insight on the in situ crystallization of calcium antimonate opacified glass during the Roman period. Applied Physics A 100:683-692

Lavagne H (1988) Operosa antra. Recherches sur la grotte à Rome de Sylla à Adrien. BEFAR, 272. Roma

Lilyquist C, Brill RH (1993) Studies in early Egyptian glass. Metropolitan Museum Of Art, New York

Maltoni S, Silvestri A (2018) A mosaic of colors: investigating production technologies of Roman glass tesserae from Northeastern Italy. Minerals 8(6):255
Maltoni S, Silvestri A, Marcante A, Molin G (2016) The transition from Roman to Late Antique glass: new insights from the Domus of Tito Macro in Aquileia (Italy). J Archaeol Sci 73:1-16

Mass J, Stone R, Wypyski M (1998) The mineralogical and metallurgical origins of Roman opaque coloured glasses. In: McCray P, The Prehistory and History of Glassmaking Technology VIII: 121-144

Meek A, Henderson J, Evans J (2012) Isotope analysis of English forest glass from the Weald and Staffordshire. J Anal At Spectrom 27: 786-795

Miedema, M., 1983. Vijfentwintig eeuwen bewoning in het terpenland ten noordwesten van Groningen $(=\mathrm{PhD}$ Dissertation Vrije Universiteit Amsterdam).

Mirti P, Lepora A, Saguì L (2000) Scientific analysis of seventh-century glass fragments from the Crypta Balbi in Rome. Archaeometry 42: 359-374

Mirti P, Davit P, Gulmini M (2001) Glass fragments from the Crypta Balbi in Rome: the composition of eighth-century fragments. Archaeometry 43:491-502

Munro B (2020) The organized recycling of Roman villa sites. Duckworth, $\mathrm{CN}$ and Wilson, A, Recycling and reuse in the Roman economy, Oxford University Press, In, pp 383-401

Nenna M D, Gratuze B (2009) Etude diachronique des compositions de verres employes dans les vases mosaiques antiques: resultats preliminaires. Annales du 17e Congres de I'Association pour L'Histoire du Verre 199-205

Nicolay JAW (2014) The splendour of power. Early medieval kingship and the use of gold and silver in the southern North Sea area (5th to 7th century AD) (= Groningen Archaeological Studies 28) Groningen: Barkhuis \& University of Groningen Library

Nicolay, J.A.W. \& G.J. de Langen (in press) Een doorsnede door Friese terpen. Landschap, bewoning en exploitatie (= Jaarverslagen van de Vereniging voor Terpenonderzoek).

Nieuwhof A (2006) De wierde Wierum (provincie Groningen). Een Archeologisch Steilkantonderzoek. (= Groningen Archaeological Studies 3) Groningen: Barkhuis \& Groningen University Library

Nieuwhof A (2011) Discontinuity in the Northern-Netherlands coastal area at the end of the Roman Period. In: Panhuysen TASM (ed), Transformations in North-Western Europe (AD 300-1000) Proceedings of the 60th Sachsensymposion 19-23 September 2009 Maastricht (= Neue Studien zur Sachsenforschung 3). Konrad Theiss Verlag, Hannover, pp 55-66

Nieuwhof A (2015) Eight human skulls in a dung heap and more ritual practice in the terp region of the northern Netherlands, $600 \mathrm{BC}$ - AD 300 (= Groningen Archaeological Studies 29) Groningen: Barkhuis \& University of Groningen Library

Nieuwhof A (2020) Luxury tableware? Terra sigillata in the coastal region of the northern Netherlands In: Rubel A, Voß H-U (Eds), Experiencing the frontier and the frontier of experience: barbarian perspectives and Roman strategies to deal with new threats (Archaeopress Roman Archaeology Vol 76) Archaeopress 94-110

Nieuwhof A, Bakker M, Knol E, Nicolay JAW, Postma D, Schepers M, Varwijk TW, Vos PC (2019) Adapting to the sea: human habitation in the coastal area of the northern Netherlands before medieval dike building. Ocean Coast Manag 173:77-89

Nieuwhof A, Gerrets D, Kaspers A, de Koning J, de Langen G, Taayke E (2020) Digging for kings, finding pottery Wijnaldum in the first millennium In: Nieuwhof A (ed), The excavations at Wijnaldum Volume 2: Handmade and wheel-thrown pottery of the first millennium $\mathrm{AD}$ (= Groningen Archaeological Studies 38) Groningen: University of Groningen \& Barkhuis Publishing, 241-261

Paynter S, Kearns T, Cool H, Chenery S (2015) Roman coloured glass in the Western provinces: the glass cakes and tesserae from West Clacton in England. J Archaeol Sci 62:66-81

Phelps M, Freestone I, Gorin Rosen Y, Gratuze B (2016) Natron glass production and supply in the Late Antique and Early Medieval near 
East: the effect of the Byzantine- Islamic transition. J Archaeol Sci 75:57-71

Picon M, Vichy M (2003) D'Orient en Occident: l'origine du verre à l'époque romaine et durant le haut Moyen Âge Échanges Et Commerce Du Verre Dans Le Monde Antique 17-31

Pöche, A (2005) Perlen, Trichtergläser, Tesserae. Spuren des Glashandels und Glashandwerks auf dem frühgeschichtlichen Handelsplatz von Gross Strömkendorf, Landkreis Nordwestmecklenburg, Schwerin (Forschungen zu Gross Strömkendorf II).

Preiß F (2010) Tesserae and glass drops. In: Willemsen A, Kik A (eds), Dorestad in an international framework New research on centres of trade and coinage in Carolingian times. Proceedings of the 1st 'Dorestad Congress' held at the Museum of National Antiquities Leiden, The Netherlands June 24-27, Turnhout, 123-134

Prummel, W (2006) Dierlijk bot. In: A. Nieuwhof (ed.), De wierde Wierum (provincie Groningen). Een archeologisch steilkantonderzoek (= Groningen Archaeological Studies 3). Barkhuis publishing \& Groningen University Library, Groningen, 31-46.

Purowski T, Dzierżanowski P, Bulska E, Wagnwer B, Nowak A (2012) Study of the glass beads from Hallstatt C-D from southwest Poland: implications for glass technology and provenance. Archaeometry 54:144-166

Rehren T, Freestone IC (2015) Ancient glass: from kaleidoscope to crystal ball. J Archaeol Sci 56:233-241

Risom T (2013) Perlemageren fra Ribe. Historien, Materialerne, Teknikkerne, Ribe

Sablerolles Y (1999) Beads of glass, faience, amber, baked clay and metal, including the production waste from glass and amber bead making In: Besteman JC, Bos JM, Gerrets DA, Heidinga HA \& de Koning J (eds). Balkema, The excavations at Wijnaldum. Reports on Frisia in Roman and Medieval Times I Rotterdam Brookfield, pp 253-287

Sablerolles Y, Henderson, J, (2012) De glasvondsten. In: Dijkstra J (ed) Het domein van de boer en de ambachtsman Een opgraving op het terrein van de voormalige fruitveiling te Wijk bij Duurstede: een deel van Dorestad en de villa Wijk archeologisch onderzocht, Amersfoort (ADC monografie 12), 293-350

Sablerolles Y, Henderson J, Dijkman W (1997) Early medieval glass bead making in Maastricht (Jodenstraat 30), The Netherlands. In: von Freeden U, Wieczorek A (eds), Perlen Archäologie, Techniken, Analysen, Akten des Internationalen Perlensymposiums in Mannheim von 11 bis 14 November 1994, Dr Rudolf Habelt GmbH, Bonn (Kolloquien zur Vor- und Frühgeschichte 1), 291-313

Sayre EV, Smith RW (1967) Some materials of glass manufacturing in antiquity. In: Elving PJ, Winefordner JD (eds) Archaeological Chemistry. Wiley and Sons Publication, New York, pp 279-312

Schepers M (2016) Gebruiksplanten in het terpen- en wierdengebied. In: A Nieuwhof (ed), Van Wierhuizen tot Achlum. Honderd jaar archeologisch onderzoek in terpen en wierden Groningen: Vereniging voor Terpenonderzoek 141-152

Schibille N, Boschetti C, Valero Tévar MÁ, Veron E, de Juan AJ (2020) The color palette of the mosaics in the Roman villa of Noheda (Spain). Minerals 10:272
Schibille N, Freestone IC (2013) Composition, production and procurement of glass at San Vincenzo al Volturno: an early medieval monastic complex in southern Italy. PLoS One 8:1-13

Schibille N, Degryse P, Corremans M, Specht CG (2012) Chemical characterisation of glass mosaic tesserae from sixth-century Sagalassos (south-west Turkey): chronology and production techniques. J Archaeol Sci 39:1480-1492

Scott RB, Degryse P (2014) The archaeology and archaeometry of natron glass making. In: Degryse P (ed) Glass making in the Greco-Roman world: results of the ARCHGLASS project. Leuven University Press $15-26$

Sear FB (1977) Roman wall and vault mosaics. Mitteilungen des Deutschen Archaeologischen Instituts, Roemische Abteilung, Dreihunderdzwanzigstes Ergänzungsheft, F.H. Kerle Verlag Heidelberg

Shortland AJ (2002) The use and origin of antimonate colorants in early Egyptian glass. Archaeometry 44:517-530

Shortland A, Tite M (2000) Raw materials of glass from Amarna and implications for the origins of Egyptian glass. Archaeometry 42: $141-151$

Silvestri A, Tonietto S, Molin G, Guerriero P (2012) The palaeo-Christian glass mosaic of St Prosdocimus (Padova, Italy): archaeometric characterisation of tesserae with antimony- or phosphorus-based opacifiers. J Archaeol Sci 39:2177-2190

Silvestri A, Tonietto S, Molin G, Guerriero P (2014) The palaeo-Christian glass mosaic of St Prosdocimus (Padova, Italy): archaeometric characterisation of tesserae with copper- or tin-based opacifiers. J Archaeol Sci 42:51-67

Stern W, Gerber Y (2004) Potassium-calcium glass: new data and experiments. Archaeometry 46:137-156

Theophilus Presbyter, De Diversis Artibus, H Böhlaus Nachf, Graz Wien, 1987, II, XXII

Theune C (2008) Die Perlen von Dunum - neue Forschungen zur Chronologie des karolingerzeitlichen Gräberfeldes von Dunum, Ldkr. Wittmund, Probleme der Küstenforschung im südlichen Nordseegebiet, 32, Oldenburg, 243-285

Tite M, Pradell T, Shortland A (2008) Discovery, production and use of tin-based opacifiers In Glasses, enamels and glazes from the Late Iron Age onwards: a reassessment. Archaeometry 50:67-84

van der Werf I, Mangone A, Giannossa LC, Traini A, Laviano R, Coralini A, Sabbatini L (2009) Archaeometric investigation of Roman tesserae from Herculaneum (Italy) by the combined use of complementary micro-destructive analytical techniques. J Archaeol Sci 36: 2625-2634

Verità M, Bjornholt B, James L, Freestone I, Henderson J, Nenna M-D, Schibille N (2009) Glossary of mosaic glass terms, centre for Byzantine cultural history. University of, Sussex

Verità M, Maggetti M, Sagui L, Santopadre P (2013) Colors of Roman glass: an investigation of the yellow sectilia in the Gorga collection. Journal of Glass Studies 55:39-52

Publisher's note Springer Nature remains neutral with regard to jurisdictional claims in published maps and institutional affiliations. 